\title{
Processing Ceramic Proton Conductor Membranes for Use in Steam Electrolysis
}

\author{
Kwati Leonard ${ }^{1,2}, * \mathbb{1}$, Wendelin Deibert ${ }^{2}$, Mariya E. Ivanova ${ }^{2}$, Wilhelm A. Meulenberg ${ }^{2}$, \\ Tatsumi Ishihara ${ }^{1}$ and Hiroshige Matsumoto ${ }^{1}$ \\ 1 International Institute for Carbon Neutral Energy Research (WPI-I2CNER), Kyushu University 744 Motooka, \\ Nishiku, Fukuoka 819-0395, Japan; ishihara@cstf.kyushu-u.ac.jp (T.I.); \\ matsumoto@i2cner.kyushu-u.ac.jp (H.M.) \\ 2 Institute of Energy and Climate Research IEK-1, Forschungszentrum Jülich GmbH, 52425 Jülich, Germany; \\ w.deibert@fz-juelich.de (W.D.); m.ivanova@fz-juelich.de (M.E.I.); w.a.meulenberg@fz-juelich.de (W.A.M.) \\ * Correspondence: kwati@i2cner.kyushu-u.ac.jp; Tel.: +81-092-802-6717
}

Received: 7 October 2020; Accepted: 9 November 2020; Published: 12 November 2020

\begin{abstract}
Steam electrolysis constitutes a prospective technology for industrial-scale hydrogen production. The use of ceramic proton-conducting electrolytes is a beneficial option for lowering the operating temperature. However, a significant challenge with this type of electrolyte has been upscaling robust planar type devices. The fabrication of such multi-layered devices, usually via a tape casting process, requires careful control of individual layers' shrinkages to prevent warping and cracks during sintering. The present work highlights the successful processing of $50 \times 50 \mathrm{~mm}^{2}$ planar electrode-supported barium cerium yttrium zirconate $\mathrm{BaZr}_{0.44} \mathrm{Ce}_{0.36} \mathrm{Y}_{0.2} \mathrm{O}_{2.9}\left(\mathrm{BZCY}(54)_{8 / 9} 2\right)$ half cells via a sequential tape casting approach. The sintering parameters of the half-cells were analyzed and adjusted to obtain defect-free half-cells with diminished warping. Suitably dense and gas-tight electrolyte layers are obtained after co-sintering at $1350^{\circ} \mathrm{C}$ for $5 \mathrm{~h}$. We then assembled an electrolysis cell using $\mathrm{Ba}_{0.5} \mathrm{La}_{0.5} \mathrm{CoO}_{3-\delta}$ as the steam electrode, screen printed on the electrolyte layer, and fired at $800{ }^{\circ} \mathrm{C}$. A typical $\mathrm{Ba}_{0.5} \mathrm{La}_{0.5} \mathrm{CoO}_{3-\delta}\left|\mathrm{BaZr}_{0.44} \mathrm{Ce}_{0.36} \mathrm{Y}_{0.2} \mathrm{O}_{3-\delta}(15 \mu \mathrm{m})\right| \mathrm{NiO}-\mathrm{SrZr}_{0.5} \mathrm{Ce}_{0.4} \mathrm{Y}_{0.1} \mathrm{O}_{3-\delta}$ cell at $600{ }^{\circ} \mathrm{C}$ with $80 \%$ steam in the anode compartment reached reproducible terminal voltages of $1.4 \mathrm{~V}$ @ $500 \mathrm{~mA} \cdot \mathrm{cm}^{-2}$, achieving $~ 84 \%$ Faradaic efficiency. Besides electrochemical characterization, the morphology and microstructure of the layered half-cells were analyzed by a combination of high-angle annular dark-field scanning transmission electron microscopy (HAADF-STEM) and energy-dispersive X-ray spectroscopy. Our results also provide a feasible approach for realizing the low-cost fabrication of large-sized protonic ceramic conducting electrolysis cells (PCECs).
\end{abstract}

Keywords: proton-conducting oxide; steam electrolysis; hydrogen production; tape casting

\section{Introduction}

Steam electrolysis has been demonstrated to be an efficient and viable method to produce high purity hydrogen using ceramics proton-conducting electrolytes (PCE) at the intermediate temperature range $\left(400 \sim 600^{\circ} \mathrm{C}\right)[1-5]$. This class of electrolytes is particularly favored for their relatively high ionic conductivity with low activation energy $(<0.5 \mathrm{eV})$ for proton conduction [6,7]. Moreover, as protons are the conducting ionic species, hydrogen is produced separately from the supplied steam, which is a significant advantage compared to devices based on oxide-ion conducting electrolytes in which the produced hydrogen is obtained mixed with steam, requiring an additional separation process. There has been an increased interest in this technology in recent years, aimed at exploiting the benefits mentioned above $[8,9]$. Significant effort has been mostly focused on developing suitable electrolyte $[6,7,10,11]$ and air electrode materials [12-15]. Whereas concerning device fabrication and assembly, progress has been 
made mainly with realizing small scale single cells having relatively small overall sizes and electrode surface area $\left(0.2 \sim 0.4 \mathrm{~cm}^{2}\right)$ [3,5,12,14-18]. For example, Duan et al. [2] recently reported a 90-98\% Faradaic efficiency on a reversible protonic ceramic electrochemical cell operating endothermically with $\sim 97 \%$ overall electric-to-hydrogen energy conversion efficiency at a current density of $\sim 1000 \mathrm{~mA} \cdot \mathrm{cm}^{-2}$. Kim et al. [19] also obtain an attractive electrolysis voltage of $1.3 \mathrm{~V}$ at a current density of $750 \mathrm{~mA} \cdot \mathrm{cm}^{-2}$ and purporting the highest electrochemical performance for hydrogen production at $600{ }^{\circ} \mathrm{C}$. Another remarkable achievement was reported by Wu et al. [20]. In their work, current densities of 210 and $880 \mathrm{~mA} \cdot \mathrm{cm}^{-2}$ at 500 and $600{ }^{\circ} \mathrm{C}$, respectively, were obtained at an applied electrolysis voltage of $1.34 \mathrm{~V}$. In our previous study, steam electrolysis voltage as low as $1.45 \mathrm{~V}$ was attainable at current densities of 0.2 and $0.5 \mathrm{~A} \mathrm{~cm}^{-2}$ at 550 and $600{ }^{\circ} \mathrm{C}$, with Faradaic efficiency $>82 \%$ using $\mathrm{BaZr}_{0.44} \mathrm{Ce}_{0.36} \mathrm{Y}_{0.2} \mathrm{O}_{3-\delta}$ as the electrolyte [3]. The improved cell performance was explained by the electrolyte's high densification promoted by a better sinter-ability of $\mathrm{NiO}-\mathrm{SrZr}_{0.5} \mathrm{Ce}_{0.4} \mathrm{Y}_{0.1} \mathrm{O}_{3-\delta}$ cathode substrate.

Although these small-sized protonic cells can successfully be deployed to reach very high hydrogen production performance, their fabrication techniques are not yet entirely rational at an industrial scale. Many factors can challenge the successful fabrication and upscale of affordable large-sized protonic devices meeting the commercial target. These large-sized devices are generally categorized as tubular or planar, with the planar type preferable for operation due to their advantages [21-23]. Nonetheless, the fabrication of such multi-layered planar devices, usually via a tape casting process, requires careful control of individual layers' shrinkages to prevent bending and cracking during sintering [22,24,25]. In many cases, an additional flattening step is also necessary to minimize the bending caused by the layers' different sintering behavior.

In recent years, various efforts to develop cost-effective processing techniques for large-sized protonic cells have somewhat advanced. Dailly and Marrony [26,27] reported on planar-type proton-conducting electrolyte cells with an active working area of $\sim 12-20 \mathrm{~cm}^{2}$. In their study, an impressive cell performance on a $4.5 \times 4.5 \mathrm{~cm}^{2}$ cell is reported under both fuel $\left(>0.25 \mathrm{~W} / \mathrm{cm}^{2}, 0.7 \mathrm{~V}\right)$ and electrolysis mode $\left(0.5 \mathrm{~A} / \mathrm{cm}^{2}, 1.3 \mathrm{~V}\right)$. They also observe stable long term operation and limited degradation rate $(-2 \% / \mathrm{kh})$ [28]. Nonetheless, even with such a good performance, the investigated cells' microstructure still requires significant optimization. Typically, for the successful fabrication of such devices with a relatively thin electrolyte layer, the fuel side electrode's microstructural integrity is critical because its surface crucially affects the thin electrolyte layer's quality. Bae et al. [29] and Himeko et al. [30] showed that over-grown $\mathrm{NiO}$ particles at the electrode interface tend to prevent a favorable microstructure at the electrolyte/electrode interface that contributes to the electrode reaction. A convenient, cost-effective processing method is thus needed to produce a desirable electrolyte/electrode interface microstructure and defect-free (without cracks, pinholes) thin electrolyte layer for better cell performance.

We focused on a well-established, low cost, sequential tape casting processing route to address some of these challenges. This advanced casting technique involves the inversion of the traditional tape casting approach's necessary manufacturing steps and produces homogeneous, large-area, flat ceramic films. This method has been used for the fabrication of solid oxide-oxygen ions conducting fuel and electrolysis cell (O-SOFC/O-SOEC) [21,23] as well as hydrogen [31,32] and oxygen separation membranes [33-35]. Another great advantage of this technique is its potential to minimize manufacturing cost since multi-layer components are laminated and co-sintered in a single step [23,35]. Here, layered planar electrode-supported barium cerium yttrium zirconate $\mathrm{BaZr}_{0.44} \mathrm{Ce}_{0.36} \mathrm{Y}_{0.2} \mathrm{O}_{3-\delta}$ half-cells were processed via a sequential tape casting route on a high shrinkage $\mathrm{NiO}-\mathrm{SZr}_{0.5} \mathrm{Ce}_{0.4} \mathrm{Y}_{0.1} \mathrm{O}_{3-\delta}$ support. The sintering parameters of the half-cells were analyzed and adjusted to obtain defect-free half-cells with diminished warping. Steam electrolysis cells were then assembled with $\mathrm{Ba}_{0.5} \mathrm{La}_{0.5} \mathrm{CoO}_{3-\delta}$ as the steam electrode. The cells reached reproducible terminal voltages of $1.4 \mathrm{~V}$ at $500 \mathrm{~mA} \cdot \mathrm{cm}^{-2}$ with $\sim 84 \%$ hydrogen production efficiency. 


\section{Materials and Methods}

Powders of $\mathrm{BaZr}_{0.44} \mathrm{Ce}_{0.36} \mathrm{Y}_{0.2} \mathrm{O}_{3-\delta}\left(\mathrm{BZCY}(54)_{8 / 9} 2\right), \mathrm{SrZr}_{0.5} \mathrm{Ce}_{0.4} \mathrm{Y}_{0.1} \mathrm{O}_{3-\delta}(\mathrm{SZCY} 541)$, and $\mathrm{Ba}_{0.5} \mathrm{La}_{0.5} \mathrm{CoO}_{3-\delta}$ (BLC) were synthesized by a modified wet solution route in house, using pre-determined concentrations of analytic grade metal nitrates $[7,36]$. Stoichiometric amounts of the following precursor's $\mathrm{Ba}\left(\mathrm{NO}_{3}\right)_{2}$ (Wako, Osaka, Japan, 99.9\%), $\mathrm{ZrO}\left(\mathrm{NO}_{3}\right)_{2}$ (Aldrich, Tokyo, Japan, 99\%), $\mathrm{Sr}\left(\mathrm{NO}_{3}\right)_{2}$ (Soekawa Chemicals, Tokyo, Japan 99.9\%), Ce(NO$)_{3} \cdot 6 \mathrm{H}_{2} \mathrm{O}$ (Kanto Chemical Co., Tokyo, Japan, INC 99.99\%), $\mathrm{Co}\left(\mathrm{NO}_{3}\right)_{2} \cdot 6 \mathrm{H}_{2} \mathrm{O}$ (Kanto Chemical Co., Tokyo, Japan, INC 99.95\%), $\mathrm{La}\left(\mathrm{NO}_{3}\right)_{3} \cdot 6 \mathrm{H}_{2} \mathrm{O}$ (Wako, city and country, 99.9\%) and $\mathrm{Y}\left(\mathrm{NO}_{3}\right)_{3} \cdot 6 \mathrm{H}_{2} \mathrm{O}$ (Mitsuwa's Pure Chemicals, Osaka, Japan, $99.9 \%$ ) were dissolved in deionized water. EDTA (Dojindo, Osaka, Japan, 99\%) and citric acid (Wako, Osaka, Japan, 99\%) were added as complexing agents in a molar ratio ereof 1:1.5:1.5.Ammonium hydroxide solution (Chameleon Regent, Osaka, Japan, $28.0 \% \mathrm{NH}_{3}$ in $\mathrm{H}_{2} \mathrm{O}$ ) was subsequently added to promote dissolution and adjust the mixture's $\mathrm{pH}$ to $\sim 9$. A dark viscous gel is formed after stirring at $160{ }^{\circ} \mathrm{C}$ for about six hours, which was then pre-fired at $240^{\circ} \mathrm{C}$ in a vacuum oven under adequate ventilation to form a solid black precursor. The powders were then calcined at $900{ }^{\circ} \mathrm{C}$ for $10 \mathrm{~h}$ in air and subsequently roll milled using zirconia balls with ethanol to produce uniform, submicrometer particles. The powders' calcination was made again at 1100 and $1300^{\circ} \mathrm{C}$ for BLC and the electrolyte, respectively. The synthesized powders' phase purity was confirmed by X-ray diffraction (Rigaku Ultima IV) with Cu-K $\alpha$ radiations (40 kV, $40 \mathrm{~mA}$ ). Diffraction patterns were obtained in the $2 \theta$ range between $10^{\circ}$ and $80^{\circ}$ with a step size of $0.02^{\circ}$. The data were subsequently refined by the Rietveld method. Large quantities of BZCY $(54)_{8 / 9} 2$ and SZCY541powders were also purchased from KUSAKA RARE METAL PRODUCTS Japan. The particle size distribution was investigated by laser diffraction using a Malvern Mastersizer 3000 granulometry (Malvern, UK) equipped with a Hydro E.V. humid dispersion unit. Their specific surface area was determined using Brunauer-Emmett-Teller analysis with nitrogen as measurement gas. Powders morphology was examined in a scanning electron microscope (SEM FEG Tescan MIRA3, Brno, Czech Republic) and (STEM-EDS; JEOL JEM-ARM200F, Hitachi HD-2300A, Tokyo, Japan). The acronym BZCY $(54)_{8 / 9} 2$, stands for: $\mathrm{Ba}=1, \mathrm{Zr}=0.5 \times 8 / 9=0.44, \mathrm{Ce}=0.4 \times 8 / 9=0.36$, and $\mathrm{Y}=0.2$.

\subsection{Fabrication of Electrode-Supported Half-Cells by Sequential Tape-Casting}

The respective layers had different suitable slurry formulations for the green tapes. The basic BZCY (54) $8 / 92$ electrolyte slurry composition was based on a previously optimized slurry composition for $\mathrm{La}_{5.4} \mathrm{WO}_{12-\delta}(\mathrm{LaWO})$ membrane fabrication [31]. A two-step procedure was used for slurry preparation. Firstly, powders, solvent, dispersant, and a pore-forming agent (for the electrode support only) were mixed to form a suspension. In the second step, a binder and plasticizers were added in a suitable ratio to make the tape flexible and resistant. The solid loading of the electrolyte slurry was 25 vol\%. For the support layer slurry, commercial $\mathrm{NiO}$ powder (Vogler, raw material) and BZCY(54) $8 / 92$ (KUSAKA RARE METAL PRODUCTS Co., LTD, Kanagawa, Japan), or in-house synthesized with a ratio of $\mathrm{NiO}: \mathrm{BZCY}(54)_{8 / 9} 2=60: 40 \mathrm{in} \mathrm{wt} \%$, were dispersed in an ethanol and methyl ethyl ketone (M.E.K.) mixture together with Nuosperse FX9086 (Elementis Specialties, Inc., London, UK) as the dispersing agent. Polyvinyl butyral (Butvar PVB-98, Solutia Inc., St. Louis, MO, USA), Solusolv 2075 (Solutia Inc., St. Louis, MO, USA), and polyethyleneglycol PEG 400 (Merck Schuchardt, Hohenbrunn, Germany) were subsequently added as plasticizers and binder, respectively, to provide mechanical stability and flexibility to the green tape. Rice starch in a weight ratio of $5 \%$ or $15 \%$ to the solid load of the support slurry was added to produce a percolating porous structure after burning out. The mixture was homogenized adequately in a Thinky ARV310CE planetary mixer and left to rest for about $48 \mathrm{~h}$ to de-air and completely dissolve the binder before casting experiments. Similarly, the functional layer's slurry consists of NiO and SZCY541 (KUSAKA RARE METAL PRODUCTS, Kanagawa, Japan) in a 60:40 weight ratio, without a pore-former, to increase the triple-phase boundaries and therefore the cathode activity.

Electrode-supported electrolyte half-cells were thus fabricated by sequential tape-casting using a KAROcast 300-7 micro-tape casting device from K.M.S. Automation GmbH Germany. The protocol 
consisted of; first, casting a thin BZCY $(54)_{8 / 9} 2$ electrolyte layer onto a silicone-coated polymeric (Polyethylene terephthalate) foil, moving with controlled speed into a vented instrument chamber. After proper drying at room temperature, a functional NiO-SZCY541 layer was cast directly on the BZCY(54) $)_{8 / 9} 2$ film followed by the support NiO-SZCY541 or NiO-BZCY(54) 8/9 $_{9} 2$ slurry with a 6-h interval for drying. This approach enables the formation of defect-free electrolyte layers because of the polymer foil's high surface quality. The as-fabricated green tapes were subsequently cut into appropriate dimensions (e.g., round and square shapes) and sintered at 1350,1400 , and $1500{ }^{\circ} \mathrm{C}$ for further characterization. Co-firing consisted of de-binding to burn out the organic components and subsequent sintering to achieve the desired microstructure. The de-binding and sintering heating ramps were adjusted to obtain defect and crack free half-cells. The minimum electrolyte, functional, and support layer thickness was $\sim 12,10$, and $400 \mu \mathrm{m}$, respectively (in the final-fired state).

Thermo-gravimetric analysis (TGA)/differential thermal analysis (DTA) was performed on tape caste $\mathrm{BZCY}(54)_{8 / 9} 2$ single electrolyte and single support layer to understand the decomposition behavior of the organic additives, using a Netzsch S.T.A. 409C system. DTA involves detecting thermal effects accompanied by physical or chemical changes by recording the temperature difference $(\Delta T)$ between the test sample and the reference sample. The measurements were performed in a constant flow of two gases: nitrogen and oxygen at ambient pressure with a heating rate of $5{ }^{\circ} \mathrm{C} / \mathrm{min}$ up to a maximum temperature of $1000^{\circ} \mathrm{C}$. The bending action of the trilayer half-cell was investigated by first, comparing the shrinkage behavior of NiO-SZCY541 and NiO-BZCY(54) $)_{8 / 9} 2$ with the BZCY(54) $)_{8 / 9} 2$ electrolyte using a TOMMI plus optical dilatometer (Fraunhofer I.S.C., Würzburg, Germany). Samples for shrinkage measurements were prepared by cutting off strips with a width of $15 \mathrm{~mm}$ from the respective green tapes and shaping them into cylinders. Round shaped green tape pieces with a $28 \mathrm{~mm}$ diameter were used for bending behavior investigations, using heating ramps of $1 \sim 4{ }^{\circ} \mathrm{C} / \mathrm{min}$ and temperatures up to $1500{ }^{\circ} \mathrm{C}$ with dwell times of up to $3 \mathrm{~h}$. Images of the sample silhouette were recorded every $60 \mathrm{~s}$ with a charge-coupled device (C.C.D.) camera during heat treatment and analyzed subsequently. Finally, the gas-tightness of the electrolyte layer $\left(50 \times 50 \mathrm{~mm}^{2}\right)$ was evaluated by helium leak rate measurements [23,37]. The helium flow through the half-cell was determined with a mass spectrometer at a pressure difference of $1000 \mathrm{hPa}$. The values were normalized to a measured area of $16 \mathrm{~cm}^{2}$ and a pressure difference of $100 \mathrm{hPa}$.

\subsection{Complete Cell Fabrication and Steam Electrolysis Measurements}

BLC electrode slurry was screen printed onto the BZCY $(54)_{8 / 9} 2$ electrolyte to form the complete cell with an active area of about 1 and $0.5 \mathrm{~cm}^{2}$ after firing at $800^{\circ} \mathrm{C} / 1 \mathrm{~h}$. Silver-Palladium pastes and platinum wires were used as current collectors and leads, respectively. Steam electrolysis cells were mounted and sealed in a Probostat (NorECS, Oslo, Norway) using pyrex glass. Humidified $80 \% \mathrm{H}_{2} \mathrm{O}$ mixed with $1 \% \mathrm{O}_{2} / 99 \% \mathrm{Ar} /\left(30 \mathrm{~mL} \cdot \mathrm{min}^{-1}\right)$ as the carrier gas was introduced to the anode and $1 \% \mathrm{H}_{2} / \mathrm{Ar} 99 \%$ $\left(30 \mathrm{~mL} \cdot \mathrm{min}^{-1}\right)$ to the cathode, humidified by saturated water vapor at $17^{\circ} \mathrm{C}\left(P_{\mathrm{H} 2 \mathrm{O}}=1.9 \times 10^{3} \mathrm{~Pa}\right)$. A hygrometer chilled mirror (UHQ-4P, Buck Research Instruments LLC, Tokyo, Japan) was used to monitor the anode inlet's water vapor pressure. The gas lines were kept heated at $120^{\circ} \mathrm{C}$ to prevent the condensation of water vapor. The hydrogen production rate was determined by measuring the increase in hydrogen concentration in the cathode gas outlet by gas chromatography (Varian CP- 4900 micro-Gas Chromatograph equipped with a micro-machined Thermal Conductivity Detector (T.C.D.), Agilent Technologies Inc., Tokyo, Japan). Faradaic efficiencies were evaluated based on the ratio between the experimental hydrogen generation rate and theoretical one at fixed current densities.

\subsection{Microstructural Observation and Characterization}

Scanning transmission electron microscopy-energy dispersive X-ray spectroscopy (STEM-EDS; JEOL JEM-ARM200F, Hitachi HD-2300A, Tokyo, Japan) was applied to analyze the top surface of the electrolyte, the half-cell as well, as the elemental distribution. Transmission electron microscopy (TEM.; JEOL JEM-ARM200F, Tokyo, Japan) was used to analyze the crystal structure. A focused ion 
beam coupled with a scanning electron microscope (FIB-SEM, Helios Nanolab 600i, Tokyo, Japan) was used to prepared TEM samples. Samples were first embedded in liquid epofix resin and a hardener, in a 9:1 ratio, and 0.4 W\% methyl ethyl ketone added to improve the viscosity. Samples were left to harden overnight and subsequently polished to a mirror finish $(0.25 \mu \mathrm{m})$ on one face using SiC grinding paper and water-based diamond suspensions sequentially. FIB was then used to obtain a micrometer-sized $\left(\sim 5 \times 5 \mu^{2}\right)$ sample, which was machined to a thickness $(<80 \mathrm{~nm})$ suitable for observation. The tape cast half-cell structures were characterized in the $\mathrm{x}-\mathrm{z}$ cross-section $(\mathrm{x}$, tape-casting direction; $z$, thickness direction).

\section{Results and Discussions}

\subsection{Phase and Structural Characterization of Powders}

X-ray diffraction patterns obtained for BZCY(54) 8/9 2 and SZCY541 powders (in house synthesized) after calcination at $1300{ }^{\circ} \mathrm{C}$ are shown in Figure $1 \mathrm{a}, \mathrm{b}$ together with derived Rietveld refinement parameters. The patterns clearly show dominant perovskite phases in agreement with previously reported results [3,7]. XRD results of the as-purchased powders calcined at $1200{ }^{\circ} \mathrm{C}$ also show a characteristic pattern similar to the latter and are presented in the supplementary Figure S1. Illustrated in Supplementary Figure S2 is the SEM morphology of both the purchased and in-house synthesized BZCY $(54)_{8 / 9} 2$ powders dispersed in the slurries used for tape-casting. The in house powder revealed sub-micrometric particles, with uniform morphology forming agglomerates of micrometers size. Whereas the purchase powder morphology seems slightly irregular with minor agglomerated particles. Laser diffraction and BET analysis estimate a mean particle size $\mathrm{d}_{50}$ of $0.65 \mu \mathrm{m}$ and a specific surface area $\left(\mathrm{A}_{\mathrm{spec}}\right)$ of $1.9 \mathrm{~m}^{2} / \mathrm{g}$ for the in house synthesized BZCY $(54)_{8 / 9} 2$ powders, while for the purchased, these values were $d_{50}$ of $0.72 \mu \mathrm{m}$ and $A_{\text {spec }}$ of $5.1 \mathrm{~m}^{2} / \mathrm{g}$. These values are entirely satisfactory for making optimal tape casting slurries $[31,37,38]$. Table 1 depicts a summary of the powder characteristics.

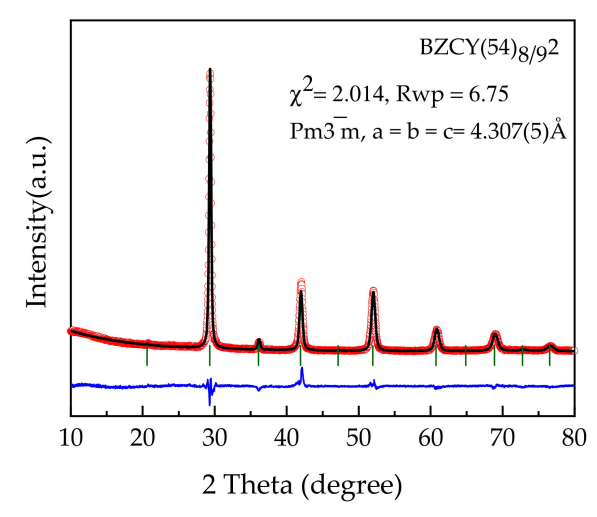

(a)

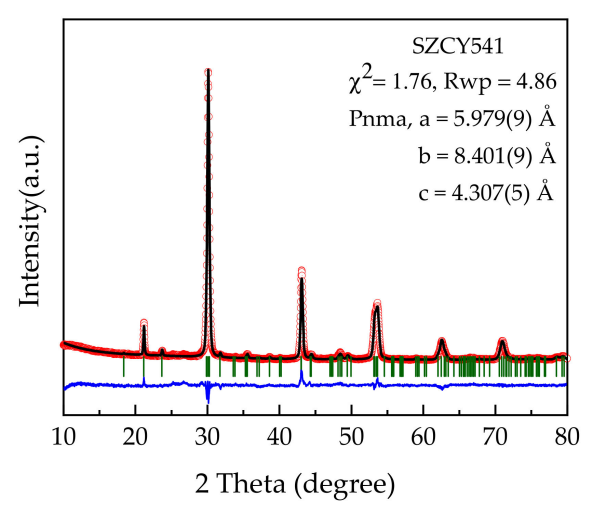

(b)

Figure 1. Rietveld refined XRD pattern of (a) BZCY(54) $8 / 92$ powder and (b) SZCY541 powder after calcination at $1300^{\circ} \mathrm{C}$ : observed X-ray diffraction intensity (black points) and calculated curve (red line). The bottom curve is the difference of the patterns, Yobs - Ycal, and the small greenish bars indicate the angular positions of the allowed Bragg reflections.

Table 1. Physical properties of the ceramic powders used for tape casting and processing.

\begin{tabular}{cccccc}
\hline Powder & $\mathbf{d}_{\mathbf{1 0}}$ & $\begin{array}{c}\text { Particle Diameter } \\
\mathbf{d}_{\mathbf{5 0}}\end{array}$ & $\mathbf{d}_{\mathbf{9 0}}$ & $\begin{array}{c}\text { Specific Surface } \\
\text { Area } \mathbf{A}_{\text {spec }}\left(\mathbf{m}^{\mathbf{2}} / \mathbf{g}\right)\end{array}$ & $\begin{array}{c}\text { Calcination } \\
\text { Temperature }\end{array}$ \\
\hline BZCY $(54)_{8 / 9}$ 2 purchased & 0.37 & 0.72 & 1.93 & 5.1 & $1200^{\circ} \mathrm{C}$ \\
SZCY541 purchased & 0.50 & 0.69 & 0.95 & 3.1 & $1200^{\circ} \mathrm{C}$ \\
BZCY(54) $8 / 9$ in house & 0.41 & 0.65 & 1.12 & 1.9 & $1300^{\circ} \mathrm{C}$ \\
SZCY541 in house & 0.50 & 0.78 & 1.25 & 1.8 & $1300^{\circ} \mathrm{C}$ \\
\hline
\end{tabular}




\subsection{Sequential Tape Casting and Characterization}

Currently, tape casting is a proven technology for large-scale ceramic components with precisely controlled surface flatness. This versatile approach requires optimally formulated ceramic slurries $[21,22,38]$. Slurries with high solids loading and low viscosity are crucial for obtaining green tape with high density and homogeneous microstructure. After optimizing both the functional NiO-SZCY541 and substrate support NiO-SZCY541/NiO-BZCY(54)8/92 layer slurries, half-cells were fabricated by sequential casting. First, a dense thin BZCY $(54)_{8 / 9} 2$ layer was cast on a polymer foil, using a $65 \mu \mathrm{m}$ doctor blade gap. An approximately 6-h interval of drying in air at room temperature results in a defect-free layer with a homogenous thickness of $\sim 16.5 \mu \mathrm{m}$ in the green state. Subsequently, the functional and substrate support layers cast successively with similar drying intervals, respectively. We noted that pinholes and other defects are prone to appear on the electrolyte layer in case the underlying sheet is not adequately dried and a subsequent layer cast ontop. In such a case, the solvent from the cast layer either dissolves or seeps into the initial thin layer, thus resulting in defects in the tape, and in the end, fired half-cell.

By controlling the doctor blade's height, the electrolyte's thickness was varied from 20 to $12 \mu \mathrm{m}$. Flat, symmetrical $25 \times 50 \mathrm{~mm}^{2}$ and $50 \times 50 \mathrm{~mm}^{2}$ planar half-cells, in the end, fired state and $22 \mathrm{~mm}$ in diameter, were routinely obtained via this procedure. Figure 2 depicts a short description of the processing technique. Adjusted casting speed, blade gabs, and some casting parameters are summarised in Table 2. The green tape produced was cut into different sample geometries; round shape $\emptyset 28 \mathrm{~mm}$, by punching and square shape $\left(65 \times 65 \mathrm{~mm}^{2}\right.$ and $\left.130 \times 130 \mathrm{~mm}^{2}\right)$ using a scalpel blade for subsequent characterization. We noted that some of the samples cut using the scalpel blade resulted in non-uniform edges, which possibly led to additional sintering warpages, especially at the corners, as observed in some of the end fired samples.

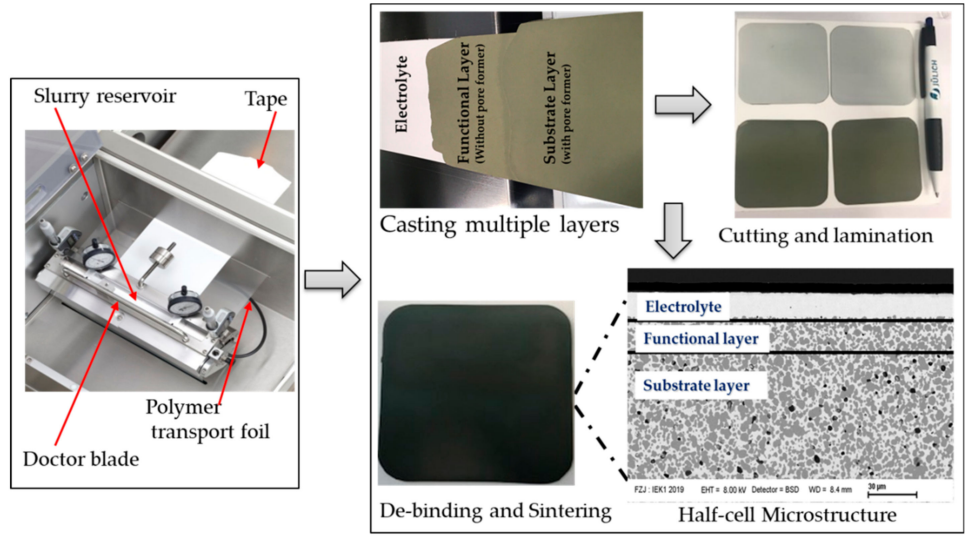

Figure 2. The sequential multi-layer processing technique of half-cell and the obtain microstructure after sintering at $1350^{\circ} \mathrm{C} / 5$.

Table 2. Summary of the tape-casting parameters, Adjusted casting speed, and blade gaps used for fabrication of the proton-conducting half-cells.

\begin{tabular}{|c|c|c|c|c|c|c|}
\hline Layer & $\begin{array}{c}\text { Blade Gap } \\
{[\mu \mathrm{m}]}\end{array}$ & $\begin{array}{c}\text { Casting Speed } \\
{[\mathrm{mm} / \mathrm{s}]}\end{array}$ & $\begin{array}{c}\text { Drying } \\
\text { Time [h] }\end{array}$ & $\begin{array}{c}\text { Green } \\
\text { Thickness }[\mu \mathrm{m}]\end{array}$ & $\begin{array}{c}\text { End Fired } \\
\text { Thickness }[\mu \mathrm{m}]\end{array}$ & Investigation \\
\hline \multicolumn{7}{|c|}{ Electrolyte } \\
\hline Electrolyte 1 & 100 & 5 & 6 & 25 & $\sim 20$ & TG/Shrinkage \\
\hline Electrolyte 2 & 75 & 5 & 5 & 18.8 & $\sim 15$ & Half-cell \\
\hline Electrolyte 3 & 55 & 5 & 5 & 13.4 & $\sim 10$ & Half-cell \\
\hline \multicolumn{7}{|c|}{ Substrate and functional layer (CFL) } \\
\hline CFL & 40 & 10 & 5 & 10 & $\sim 8$ & Half-cell \\
\hline Substrate & 1200 & 2.5 & $\sim 10-12$ & 502 & 390-400 & Half-cell \\
\hline
\end{tabular}


The co-sintering of multi-layer systems generally requires an appropriate temperature program to avoid the creation and propagation of defects while the removal of the organic additive takes place. A proper understanding of the organic additive's thermal behavior is essential to minimize undesirable defects such as cracks, warpage, or delamination occurring during sintering. Hence, a suitable heating schedule and sufficient holding time at every intermediate stage are necessary to prevent the latter. For this purpose, simultaneous TG/DTA coupled to quadrupole mass spectrometer was performed on the green tapes to understand the organic additives' decomposition behavior. Measurements were performed on the BZCY(54) $8 / 92$ electrolyte, NiO-SZCY541, and NiO-BZCY $(54)_{8 / 9} 2$ single layers. Figure 3 presents TG/DTA curves for the BZCY $(54)_{8 / 9} 2$ single electrolyte layer. The curve reveals three successive distinct regions of mass changes corresponding to a total mass loss of $17.9 \%$ recorded in the temperature range $\sim 56.5^{\circ} \mathrm{C}$ to $480{ }^{\circ} \mathrm{C}$, beyond which no further mass loss was observed up to $1000{ }^{\circ} \mathrm{C}$. The first region connects with a DTA endothermic trench down to $56.5^{\circ} \mathrm{C}$, which may be associated with the release of residual solvents (and/or a minute amount of adsorbed water on the surface of the tape). The second is connected with two endothermic peaks with maxima at 168 and $280^{\circ} \mathrm{C}$ associated with an intensive release of organic additives [39-42]. These temperature ranges happen to also correspond with reported regimes $\left(\sim 270{ }^{\circ} \mathrm{C}-340^{\circ} \mathrm{C}\right.$ and $\left.340{ }^{\circ} \mathrm{C}-400{ }^{\circ} \mathrm{C}\right)$ for PEG-400, and PVB-98 burnout in green tapes, respectively [37-40].

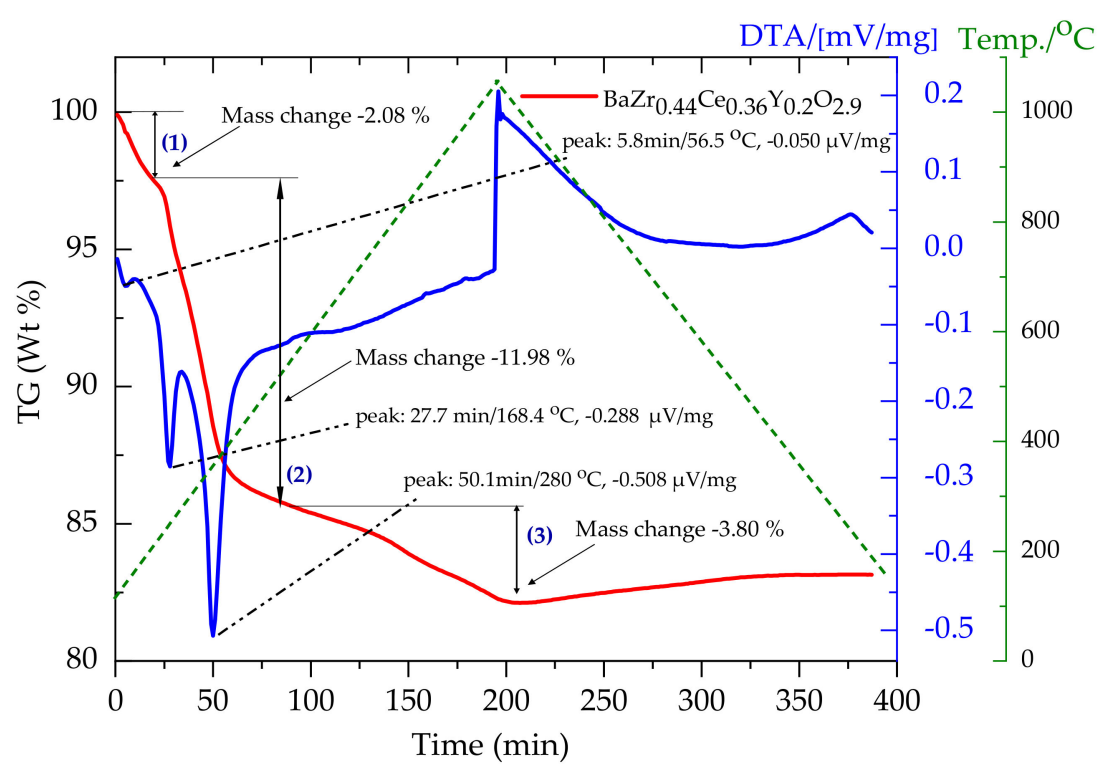

Figure 3. Thermogravimetric analysis (red curve)/differential thermal analysis (DTA blue curve) curve of BZCY $(54)_{8 / 9} 2$ electrolyte as measured in the coupled TG/DTA-MS system.

For a better comprehension of the evolved residual components during the thermal decomposition, TG/DTA-MS analyses carried out on NiO-BZCY $(54)_{8 / 9} 2$ single electrode layer is presented in Figure 4. As observed, the weight loss increases slowly up to $\sim 174{ }^{\circ} \mathrm{C}$, after which a sharp increase of $\sim 20 \%$ in the temperature range $175-404{ }^{\circ} \mathrm{C}$ appeared. The DTA curve shows four major endothermic peaks trenching down to $189,305,325$, and $383^{\circ} \mathrm{C}$. The first three peaks connect with MS spectra of $m / z=17$, $18,26,27$, and 44 ion fragments. The $m / z=17\left(\mathrm{OH}^{+}\right), 18$, are the characteristic MS values for $\mathrm{H}_{2} \mathrm{O}$. Similarly, the $\mathrm{m} / \mathrm{z} 44\left(\mathrm{CO}_{2}{ }^{+}\right)$curve is indicative of the possible release of $\mathrm{CO}_{2}$. TG/DTA-MS analyses carried out on NiO-SZCY541 single layers showed similar burn out characteristics and presented similar MS signal patterns with common $m / z$ ions fragments (data not shown). 


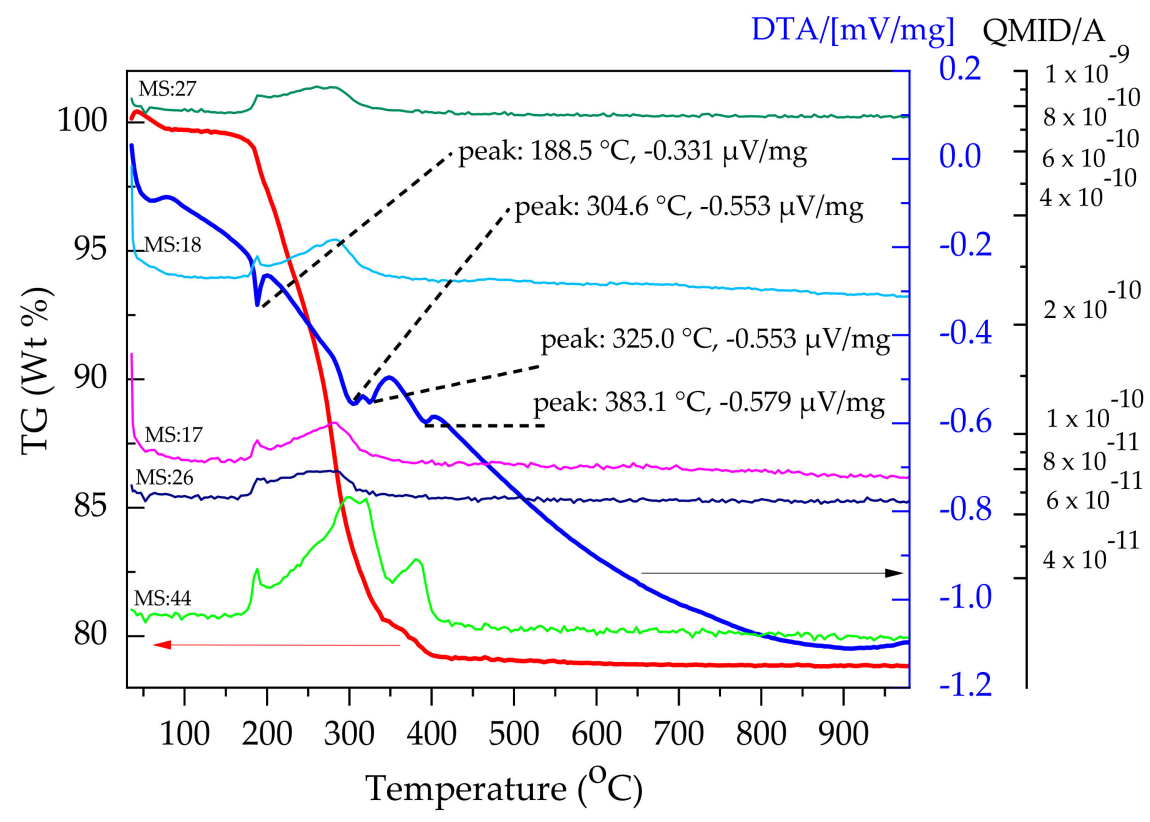

Figure 4. Thermogravimetric mass spectrometric coupled analyses of NiO-BZCY(54)8/92 layer TG, DTA curves with the total ion current plot of the evolved residues.

Based on the above thermogravimetric analysis in Figures 3 and 4, a sintering profile for the half-cells was formulated with a $1{ }^{\circ} \mathrm{C} / \mathrm{min}$ heating rate. Subsequently, a holding stage at $300^{\circ} \mathrm{C}$ for $30 \mathrm{~min}$ to sufficiently burn out the additives and another at $600^{\circ} \mathrm{C}$ to complete the decomposition of the residual polymer.

\subsection{Sinterability and Bending Behavior of the Half-Cell}

Lowering the sintering temperature of the $\mathrm{BaZr}_{1-\mathrm{x}-\mathrm{y}} \mathrm{Ce}_{\mathrm{x}} \mathrm{Y}_{\mathrm{y}} \mathrm{O}_{3-\delta}(\mathrm{BZCY})$ based half-cell below $1300{ }^{\circ} \mathrm{C}$ is our utmost desire to limit Ba loss via evaporation during sintering. Ba loss is expected to be detrimental to electrolyte performance, as the conductivity of BZCY is known to be highly sensitive to Ba content $[7,43]$. A suitable electrode support, in principle, plays a crucial role in determining the co-sintering temperature at which the electrolyte layer is fully densified. In our previous study, we found that $\mathrm{NiO}-\mathrm{SrZr}_{0.5} \mathrm{Ce}_{0.4} \mathrm{Y}_{0.1} \mathrm{O}_{3-\delta}$ electrode substrate positively influenced the densification of BZCY $(54)_{8 / 9} 2$ layer on a $20 \mathrm{~mm}$ diameter half-cell configuration. Nonetheless, the co-firing of planar multi-layered half-cells are often more challenging due to the constituent layers' different sintering behavior. The properties of the co-sintered individual layers are inevitably affected by stresses due to shrinkage mismatch at the interfaces as a result of the different thermal expansion of each segment and different sintering kinetics. Such stress could create processing defects like micro-cracks, warpage, or delamination at the interface between the layers. The sintering shrinkage of the NiO-SZCY541, $\mathrm{NiO}-\mathrm{BZCY}(54)_{8 / 9} 2$ substrates, and the half-cells were obtained from the height reduction of the cylinders [31,44]. Both composites display different shrinkage behaviors, exhibiting a maximum shrinkage rate at $\sim 1350{ }^{\circ} \mathrm{C}$ for NiO-SZCY 541 and $1450{ }^{\circ} \mathrm{C}$ for NiO-BZCY $(54)_{8 / 9} 2$, consistent with our previous work [3]. The NiO-SZCY541 and NiO-BZCY(54) $)_{8 / 9} 2$ half-cell shrunk about 27 and $\sim 33 \%$, respectively after sintering at $1500{ }^{\circ} \mathrm{C}$, whereas the $\mathrm{BZCY}(54)_{8 / 9} 2$ electrolyte only layer shrunk $\sim 9.8$ after sintering at the same temperature.

Figure 5 shows a plot of the shrinkage rates $d\left(\Delta l / l_{0}\right) / d t$ as a function of time and temperature obtained from the change in cylinder height for BZCY $(54)_{8 / 9} 2$ and NiO-BZCY $(54)_{8 / 9} 2$, respectively. Five respective regions are distinguished (denoted as I, II, III, IV, and V), representing the sintering process during heating and cooling. Region (III) represents the primary area where sintering is dominant, although sintering continues throughout the dwell time (IV) at $1500^{\circ} \mathrm{C}$. While the initial sharp strain 
observed in the region (I) could be attributed to possible shrinkage due to the rapid release of residual solvents and a small amount of surface absorbed water, as discussed above. There was practically no difference in the sintering behavior between the two specimens in region II. The red curve designates the BZCY $(54)_{8 / 9} 2$ electrolyte, while the green represents the NiO-BZCY $(54)_{8 / 9} 2$ electrode substrate. The NiO-BZCY $(54)_{8 / 9} 2$ substrate exhibited a higher sintering rate than that of the BZCY $(54)_{8 / 9} 2$ electrolyte during thermal treatment. Figure $5 \mathrm{~b}$ shows the mismatch of the sintering rates represented by the difference between the individual sintering rates of BZCY $(54)_{8 / 9} 2$ electrolyte and $\mathrm{NiO}-\mathrm{BZCY}(54)_{8 / 9} 2$. The stresses generated by the different sintering rates are the primary cause for the deformation of the half-cells, precisely the warpage or bending, observed upon co-firing in this work. The difference in the densification behavior is primarily due to the $\mathrm{NiO}$ phase in the composite substrate. $\mathrm{NiO}$ particles possibly form a constrained matrix surrounding $\mathrm{BZCY}(54)_{8 / 9} 2$ particles, thus imposing compressive stress on them, allowing them to shrink faster [28,42]. Cai et al. [45-47] made calculations on the tensions that arise during densification of a bi-layer and concluded that bi-layers would, in principle, curve towards the layer that shrinks faster, with the degree of curvature, $k$, due to mismatch of the shrinkage rates expressed using the following equation:

$$
k=\frac{t_{1}+t_{2}}{r}=\frac{6(m+1)^{2} m n}{m^{4} n^{2}+2 m n\left(2 m^{2}+3 m+2\right)+1} \cdot \Delta \varepsilon
$$

where $t_{1}$ and $t_{2}$ are the thickness of layers 1 and $2, r$ the radius of curvature, $\Delta \varepsilon$ is the strain rate mismatch between the layers, $m$ the ratio of layer thickness, $n$ the viscosity ratio between the layers. As expected, the BZCY $(54)_{8 / 9} 2 / \mathrm{NiO}-\mathrm{BZCY}(54)_{8 / 9} 2$ half-cells could not be obtained without an extreme warping, especially pronounced at the edges for most of the end fired specimens. Figure 6 shows images of some $50 \times 50 \mathrm{~mm}^{2}$ planar BZCY $(54)_{8 / 9} 2$ based half-cells with a $30 \%$ solid loading of the NiO-BZCY $(54)_{8 / 9} 2$ electrode substrate. As observed, the half-cells all appear curved toward the electrolyte top layer with warped edges. A much stronger curvature was systematically observed, with lower solid loading of the substrate. It is essential to note here that all other processing parameters were initially optimized and fixed at the same conditions except for the substrate support's solid loading.
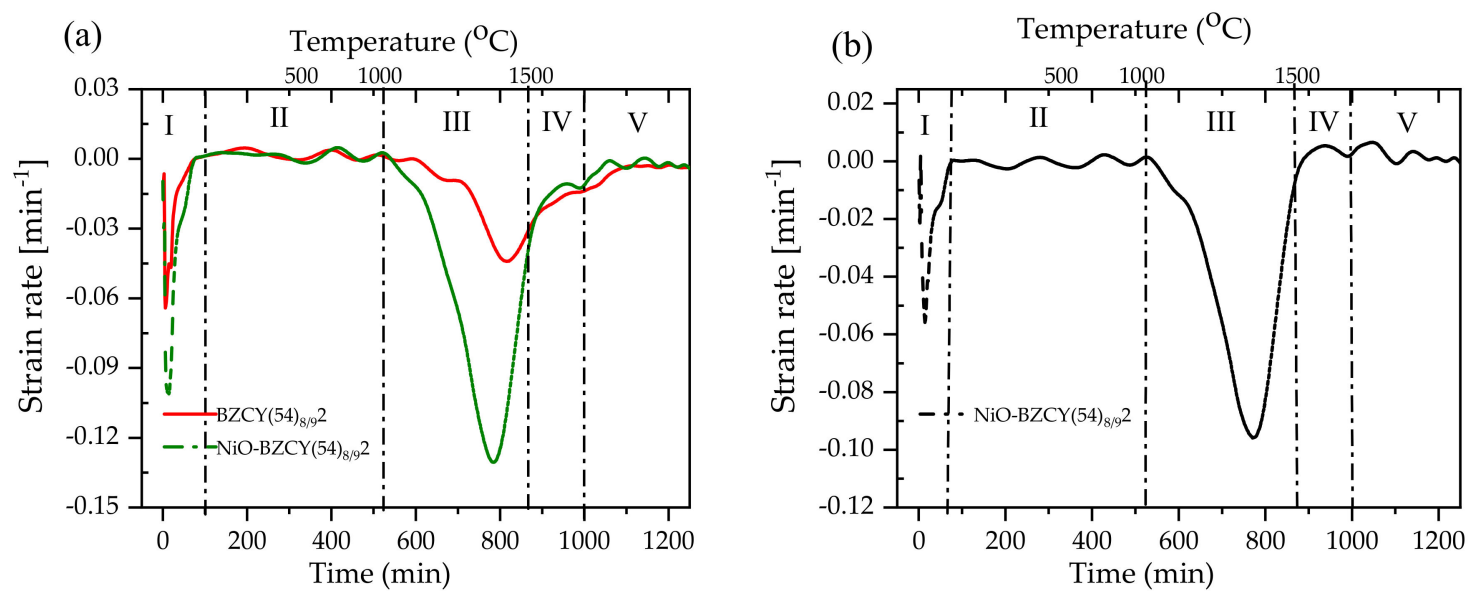

Figure 5. (a) Strain rates of the tape-casted BZCY $(54)_{8 / 9} 2$ and NiO-BZCY(54) $)_{8 / 9} 2$ support substrates (b) Mismatch of strain rates (the difference between individual strain rates BZCY $(54)_{8 / 9} 2$ and NiO-BZCY $(54)_{8 / 9} 2$ ) between BZCY $(54)_{8 / 9} 2$ and $\mathrm{NiO}-\mathrm{BZCY}(54)_{8 / 9} 2$ support substrates determined as the net difference between the curves in Figure 5. 

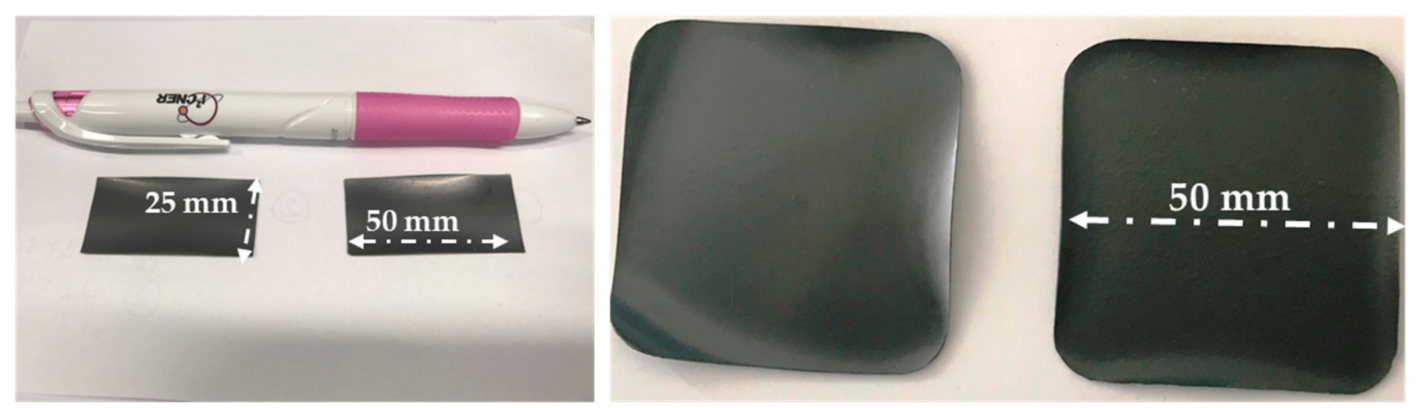

Figure 6. Images of some of the initial $25 \times 50 \mathrm{~mm}^{2}$ and $50 \times 50 \mathrm{~mm}^{2}$ planar BZCY(54) 8/9 $_{9} 2$ based half-cells, in the end, fired state showing warpage, especially pronounced at the edges.

Therefore, the change of the curvature and warpage is mainly attributed to the variation in solid loading. The observed warpage and bending are due to strain rate mismatch between the layers and likely due to non-uniform green tape edges, obtained using the scalpel blade while cutting. To establish a suitable sintering profile that enables the preparation of flat half-cells with the desired microstructure. The thermal behavior of the half cells was further investigated in detail using optical dilatometry. Figure 7 shows a sequence of selected photographs of the shape evolution and bending behavior of the half-cell during sintering (with the BZCY $(54)_{8 / 9} 2$ layer facing upwards). For all the samples investigated, no apparent bending is observed within the initial stages of sintering until around $1000 \sim 1200{ }^{\circ} \mathrm{C}$, where a slightly convex shape occurred with the half-cell curving towards the NiO-BZCY $(54)_{8 / 9} 2$ support side. This may result from the $\mathrm{NiO}-\mathrm{BZCY}(54) 8 / 92$ support faster sintering compared to the $\mathrm{BZCY}(54)_{8 / 9} 2$ electrolyte layer, consistent with the above discussion. This shape remains up to about $1250{ }^{\circ} \mathrm{C}$, where the curvature rate inverts. The half-cells begin to curve towards the electrolyte side. The most substantial curvature toward the electrolyte layer occurred at a temperature of about $1400^{\circ} \mathrm{C}$. With further heat treatment to $\sim 1500{ }^{\circ} \mathrm{C}$, the observed bending begins to be compensated mainly by the $\mathrm{NiO}-\mathrm{BZCY}(54)_{8 / 9} 2$ electrode substrate. After a dwelling period of $3 \mathrm{~h}$ at $1500{ }^{\circ} \mathrm{C}$, the half-cell is entirely flat and retains this configuration up to the end of the sintering process. This curvature evolution of the BZCY $(54)_{8 / 9} 2$ based half-cell seems consistent with in-situ observations made by Costa and Ravi et al. [22,48].

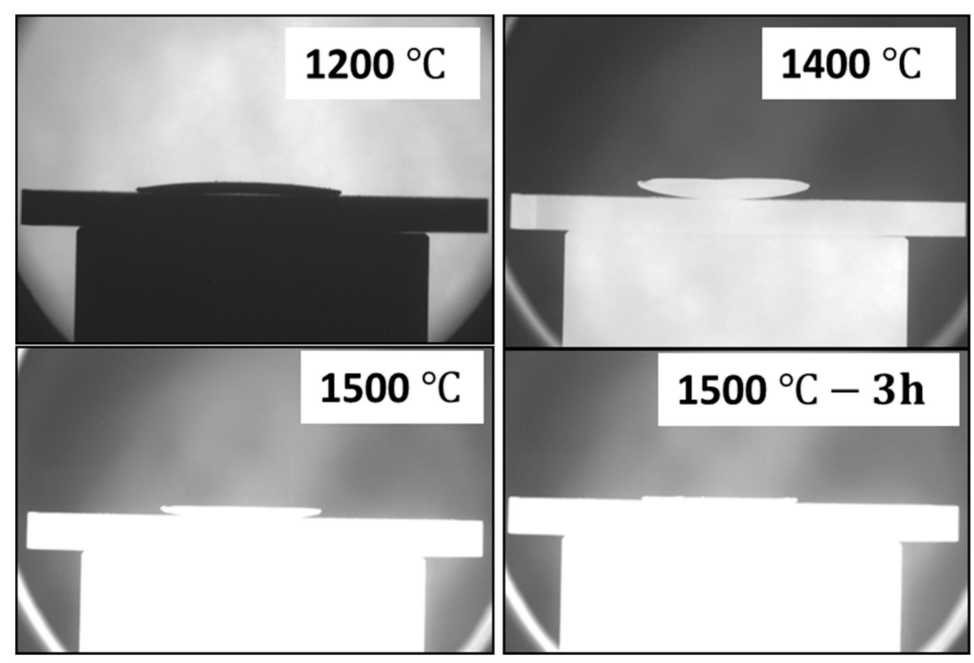

Figure 7. Selected sequence showing the curvature developed upon co-firing the BZCY(54) $8 / 92$ half-cell taken with the optical dilatometer. (Electrolyte layer is facing upward with the $\mathrm{NiO}-\mathrm{BZCY}(54)_{8 / 9} 2$ underneath).

However, we did not observe the BZCY $(54)_{8 / 9} 2$ electrolyte's initial sintering as they did. The solid loading variation revealed an optimum $\mathrm{NiO}-\mathrm{BZCY}(54)_{8 / 9} 2$ solid loading of $31 \mathrm{vol} \%$. Based on the above investigations, a slow heating rate and the introduction of a dense functional layer were 
very beneficial for limiting the developed curvature during the sintering process. However, for the planer type cells, the optimum solid substrate loading and sintering profile weren't enough to obtain planar cathode-supported half-cells. Curvature formation still occurs though crack and warpage issues were eliminated. Therefore to control the half-cells' planarity, the green cathode substrate thickness was increased from $\sim 400 \mu \mathrm{m}$ to $500 \mu \mathrm{m}$ and resulted in flatting at the end fired state. By increasing, the cathode thickness, the planar half-cell strength is enhanced, and thus the overall half-cell curvature mitigated. Figure 8 shows photographic images of the as-fabricated round shape half-cell with different configuration (half-cell type A D) and typical dimension before and after sintering. Each cell type is also described in the Figure and differ mostly at the cathode substrate. The half-cell remained flat after sintering without camber or warping for half-cell type B. Half-cell A, C, and D, even though somewhat flat, however, continue to show pronounced edge warpage, typically bending toward the substrate. The observation contrasts the edge warpage demonstrated by the $25 \times 50 \mathrm{~mm}^{2}$ and $50 \times 50 \mathrm{~mm}^{2}$ planar BZCY $(54)_{8 / 9} 2$ based half-cells shown in Figure 6 . The edge warpage is slightly reduced for half-cell type $\mathrm{C}$ when sintered at $1350^{\circ} \mathrm{C}$. More detailed experimental investigation and numerical calculation models are still necessary to thoroughly understand the curvature evolution of BZCY based half-cells during sintering. Another noticeable observation was that the sintering mismatch is most pronounced for the configuration based on the NiO-SZCY541 electrode and BZCY $(54)_{8 / 9} 2$ electrolyte, inferring that the co-shrinking NiO-SZCY541 support influences the densification behavior of BZCY $(54)_{8 / 9} 2$ significantly. Suitably dense and gas-tight BZCY $(54)_{8 / 9} 2$ layers are obtained after co-sintering with $\mathrm{NiO}-\mathrm{SZCY} 541$ at $1350{ }^{\circ} \mathrm{C}$, whereas the densification of the tri-layered NiO-BZCY $(54)_{8 / 9} 2$ based half-cell typically occurred at $1450{ }^{\circ} \mathrm{C}$. The co-sintered layers' densities also exceeded the density of the BZCY $(54)_{8 / 9} 2$ free layers at $1450^{\circ} \mathrm{C}$.

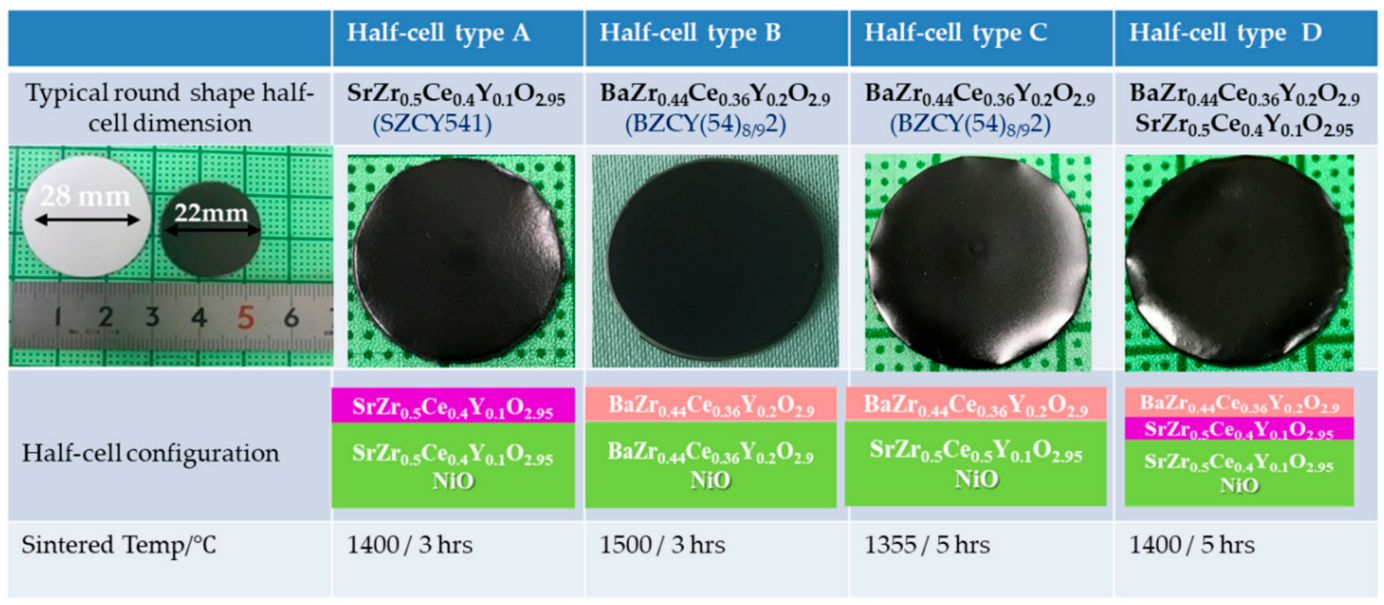

Figure 8. Photographic images of the as-fabricated round shape half-cell with different configurations (half-cell type A D), typical dimension before and after sintering, and the sintering temperature.

The observed sintering evolution behavior was reproduced with the planar half-cells $(65 \times 65 \mathrm{~mm} \times 0.530 \mathrm{~mm})$, including the NiO-SZCY541 functional layer. Leak rate testing of the half-cells with helium showed an excellent gas tightness for both the sintered flat $22 \mathrm{~mm}$ diameter and $50 \times 50 \mathrm{~mm}^{2}$ planar electrolyte layers. With an average leak rate of $5.17 \times 10^{-5}$ and $4.41 \times 10^{-6} \mathrm{hPa} \mathrm{dm}{ }^{3}\left(\mathrm{~s} \cdot \mathrm{cm}^{2}\right)^{-1}$ for BZCY $(54)_{8 / 9} 2$ sintered at 1355 and $1400{ }^{\circ} \mathrm{C}$, respectively. Moreover, planar SZCY541, $50 \times 50 \mathrm{~mm}^{2}$ half-cells generally showed better gas tightness, with an average leak rate of $6.83 \times 10^{-6} \mathrm{hPa} \mathrm{dm}{ }^{3}\left(\mathrm{~s} \cdot \mathrm{cm}^{2}\right)^{-1}$ after sintering at $1400^{\circ} \mathrm{C}$. These leak rate values are comparable and well within the threshold for high-quality reported SOEC and SOFC gas-tight electrolytes [21,23]. 


\subsection{Microstructure and Surface Morphology}

Figure 9 shows the cross-section and surface morphology of some selected half and single cells. A well-organized, multi-layered structure without visible deformation, delamination, or cracks is observed (Figure 9a,b). The resulting NiO-SZCY541 electrode functional layer and BZCY(54)8/92 electrolyte layer are homogeneous with estimated thicknesses of about 10 and $15 \mu \mathrm{m}$, respectively, after sintering at $1355^{\circ} \mathrm{C}$. The NiO-SZCY541 layer adheres well to the BZCY $(54)_{8 / 9} 2$ layer and forms an excellent percolating network, which should, in principle, lead to more triple-phase boundaries accessible for charge species and, thus, is expected to enhance the cathodic reaction. Figure $9 \mathrm{c}$ presents a complete cell's typical microstructure with the half-cell sintered at $1450{ }^{\circ} \mathrm{C}$ for $5 \mathrm{hrs}$. The NiO-BZCY $(54)_{8 / 9} 2$ substrate layer, the NiO-SZCY54 functional layer, the $\mathrm{BZCY}(54)_{8 / 9} 2$ electrolyte, and the steam electrode layers (BLC) each adheres well to the adjacent layer after sintering. However, the BZCY $(54) 8 / 92$ electrolyte phase's systematic contamination by secondary phase precipitates of yttrium-rich barium nickel oxides was observed (see Figure S3). The contamination is even more severe at $1500{ }^{\circ} \mathrm{C}$, mostly distributed at the interfaces and on the outer surface. A possible reason for this behavior could be the A-site substitution of $\mathrm{Ba}$ atoms by $\mathrm{Ni}$ and $\mathrm{Y}$ species $\left(\mathrm{BaY}_{2} \mathrm{NiO}_{5}\right.$ phase) during sintering $[49,50]$. Ba loss via evaporation is known to occur during sintering in air, and the loss amount turns to increases with increasing sintering temperature [41]. Lee et al. [51] have also reported on the formation $\mathrm{BaY}_{2} \mathrm{NiO}_{5}$ phase in $\mathrm{BZCY}$ based electrolyte and suggested that it assist the electrolyte densification. Figure $9 \mathrm{~d}$ shows a cross-sectional view of a fractured type $\mathrm{C}$ single-cell. As observed, the different layers also adhered well to each other, and the electrolyte layer is dense and free of pinholes. Figure 9e also displays that the BZCY $(54)_{8 / 9} 2$ electrolyte layer is fully dense, and the grain size is in micron-scale and about 7 8 $\mu \mathrm{m}$ with no pores. To understand the chemical compositions of the as fabricated half-cells, EDS and STEM investigations were performed on half-cell sintered at $1500^{\circ} \mathrm{C}$.
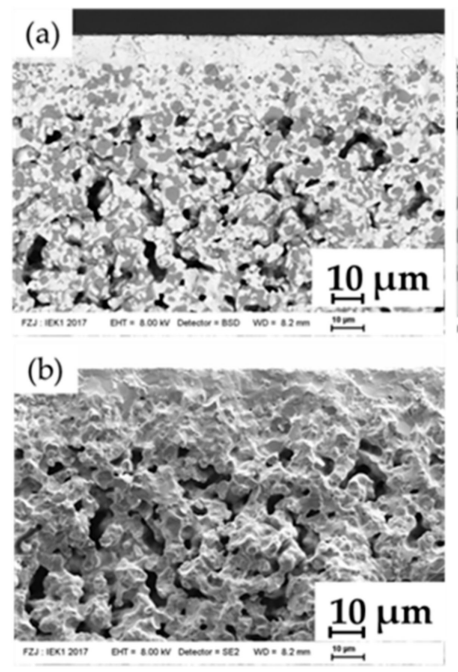

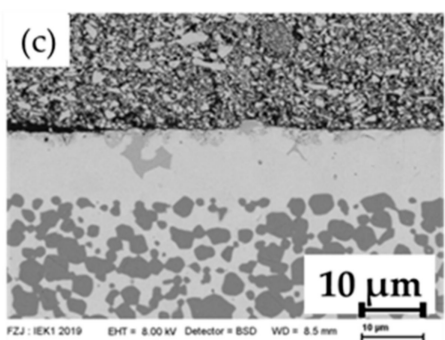

(e)

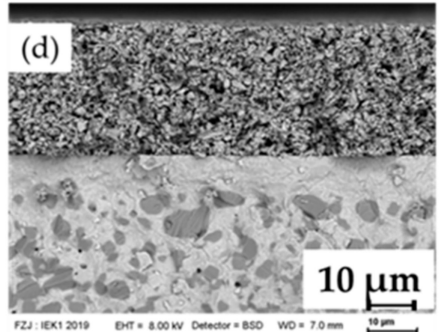

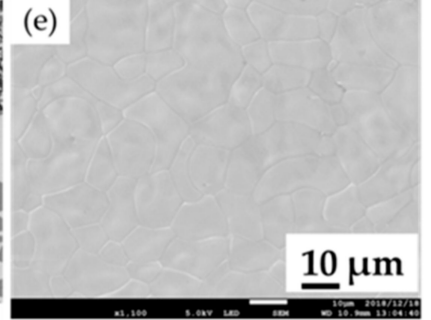

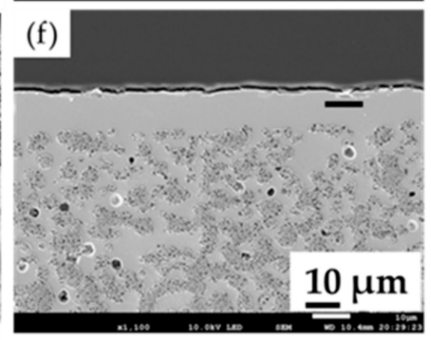

Figure 9. Scanning electron microscopy images of the as-fabricated BZCY(54) $8 / 92$ electrolyte based cell. (a) BSD-SEM observation of a fracture cross-section of the BZCY(54) $8 / 92 / \mathrm{NiO}-\mathrm{SZCY} 541 / \mathrm{NiO}-\mathrm{BZCY}(54)_{8 / 9} 2$ half-cell. (b) Fracture cross-section of the NiO-BZCY(54) 8/9 $_{9} / \mathrm{NiO}-\mathrm{SZCY} 541 / \mathrm{BZCY}(54)_{8 / 9} 2$ half-cell. (c,d) The microstructure of a single cell composed of BLC electrode anode (half-cell sintered at 1450 and $1350{ }^{\circ} \mathrm{C}$ respectively) (e) Typical surface view of the BZCY $(54)_{8 / 9} 2$ layer after sintering. (f) polished cross-section of a half-cell after $\mathrm{NiO}$ reduction.

Figure 10 shows the SEM image of a polished cross-section of the BZCY $(54)_{8 / 9} 2 / \mathrm{NiO}-\mathrm{SZCY} 541 /$ $\mathrm{NiO}-\mathrm{BZCY}(54)_{8 / 9} 2$ half-cell with the corresponding EDS elemental maps of $\mathrm{Ni}, \mathrm{Sr}, \mathrm{Zr}, \mathrm{Y}, \mathrm{Ba}, \mathrm{Ce}$. However, the maps confirm no perceivable $\mathrm{Ni}$ diffusion from the substrate to the $\mathrm{BZCY}(54)_{8 / 9} 2$ electrolyte, at least within the instrument resolution limits. The maps further reveal $\mathrm{Sr}$ is 
predominantly present and uniformly distributed throughout the BZCY $(54)_{8 / 9} 2$ electrolyte, overlapping with $\mathrm{Ba}$, thus suggesting significant Sr segregation upon sintering at $1500{ }^{\circ} \mathrm{C}$. The $\mathrm{Ni}$ area also reveals the presence of Ba spread entirely throughout the observed region. The spreading of elements is attributed primarily to barium and cerium's evaporation from the BZCY(54) $8 / 92$ phase during sintering at $1500{ }^{\circ} \mathrm{C}$. Ba evaporation in BZCY $(54)_{8 / 9} 2$ is consistent with common observations in barium cerate and zirconate based materials that invariably experienced deficiency in the Ba site after high-temperature sintering $[41,47,48]$.
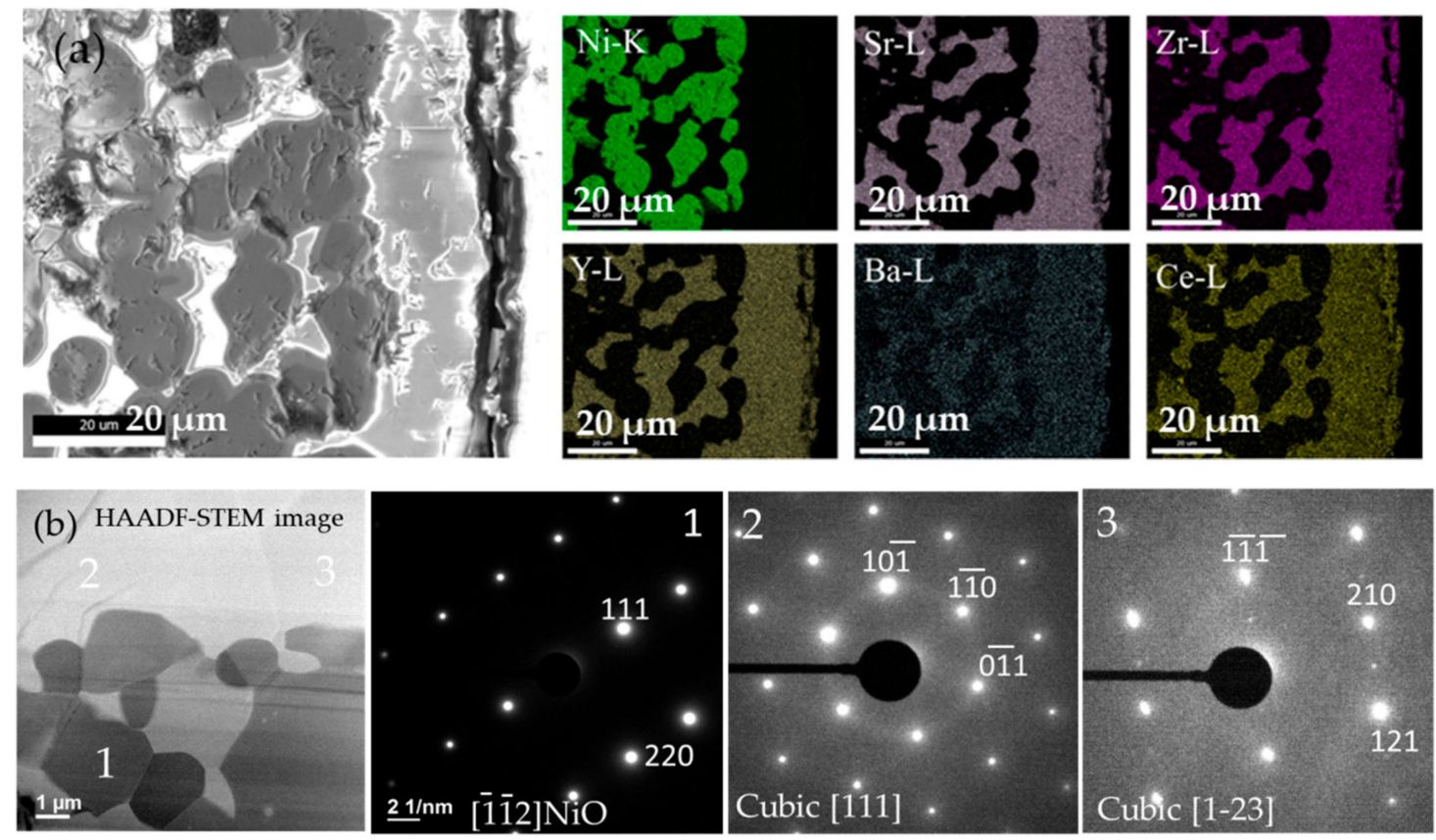

Figure 10. (a) SEM and STEM analysis of NiO-BZCY(54) $8 / 92 / \mathrm{NiO}-\mathrm{SZCY} 541 / \mathrm{BZCY}(54)_{8 / 9} 2$ half-cell with corresponding EDS maps of Ni, Sr, Zr, Y, Ba, Ce. (b) High-angle annular dark-field (HAADF) micrograph of the BZCY $(54)_{8 / 9} 2 / \mathrm{NiO}-\mathrm{BZCY}(54)_{8 / 9} 2$ support substrate interface and selected-area electron diffraction pattern. The Miller indices and crystallographic direction labeled are those of Ni and BZCY(54) $8 / 92$.

A substantial amount of Ba loss is also observed, as indicated by the color contrast in the Ba map. The EDS maps for the sample sintered at $1355^{\circ} \mathrm{C}$ (data not shown) indicate that the element distribution is somewhat more homogeneous and that no significant elemental enrichment exists in BZCY(54) $8 / 92 / \mathrm{NiO}-\mathrm{SZCY} 541 / \mathrm{NiO}-\mathrm{BZCY}(54)_{8 / 9} 2$ matrix entirely. More detailed microstructural observations were made via selected-area electron diffraction (SAED). Figure 10b show SAED patterns taken from the BZCY $(54)_{8 / 9} 2 / \mathrm{NiO}-\mathrm{BZCY}(54)_{8 / 9} 2$ support on the $\mathrm{Ni}$ and BZCY $(54)_{8 / 9} 2$ surface (spot 1, 2, and 3). A high-resolution TEM (HRTEM) image of area 1 (Figure 10b) resolved the [111] and [220] lattice fringes along the [112] zone axis of the Ni. Spot 2 and 3 viewed along the [111] and [123] direction showed lattice planes with a $0.419 \mathrm{~nm}$ spacing attributed to the cubic BZCY(54) $8 / 92$ structure. This is consistent with the XRD spectrum acquired from the same sample.

\subsection{Single-Cell Performance}

To investigate the steam electrolysis performance, BLC was chosen as the steam electrode and applied onto the dense electrolyte surface by screen printing followed by sintering at $800{ }^{\circ} \mathrm{C}$ for $1 \mathrm{~h}$. Figure 11 shows typical I-V characteristics of single-cells made from type $\mathrm{B}$ and $\mathrm{C}$ based half-cells, BLC|BZCY (54) $8 / 92 \mid \mathrm{Ni}-\mathrm{BZCY}(54)_{8 / 9} 2$ and BLC|BZCY(54) $8 / 92$ |Ni-SZCY54 under the supply of humidified $80 \% \mathrm{H}_{2} \mathrm{O}$ diluted with $1 \% \mathrm{O}_{2} / 99 \%$ Ar to the anode and $1 \% \mathrm{H}_{2} / \mathrm{Ar} 99 \%$ at the cathode as the sweep gas. The former cell configuration's open-circuit voltage was $0.79 \mathrm{~V}$ at $600{ }^{\circ} \mathrm{C}$, verifying that the electrolyte layer was dense enough to ensure sufficient gas tightness. 

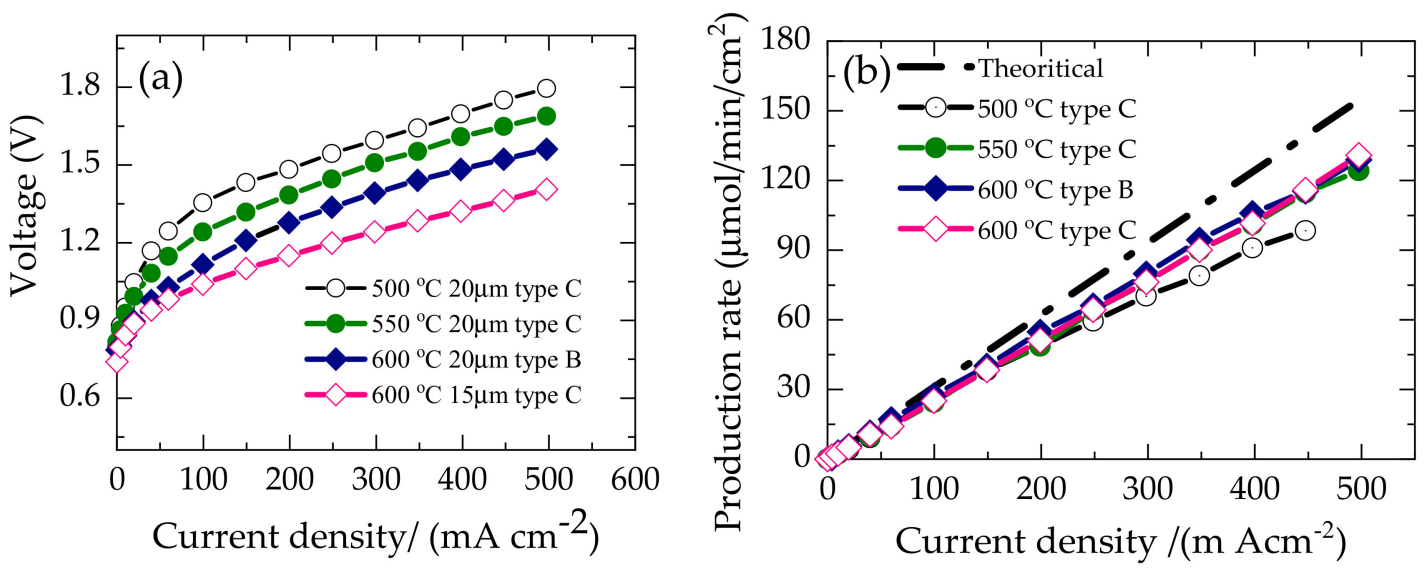

Figure 11. (a) Temperature dependence I-V characteristic of the as-fabricated steam electrolysis cells based on Type B and C half-cell configuration (b) Hydrogen evolution rate measured at 500, 550, and $600{ }^{\circ} \mathrm{C}$.

Voltages of $0.75,0.82$, and $0.80 \mathrm{~V}$ were obtained from the latter at 600,550 , and $500{ }^{\circ} \mathrm{C}$, respectively. However, the measured values are slightly lower than the theoretically obtained values of $0.83,0.86$, and $0.88 \mathrm{~V}$ at 600,550 , and $500{ }^{\circ} \mathrm{C}$, from the Nernst equilibrium equation (Equation (2)) shown below for a proton conductor under these gas atmospheres. This deviation is due to limited p-type electronic conductivity in the BZCY(54) $)_{8 / 9} 2$ electrolyte layer [7,52-54], with the possible existence of minute pinholes on the electrolyte layer, facilitating little cathode/gas crossflow.

$$
E=\frac{R T}{2 F} \ln \left(\frac{P H_{2, \text { cathode }}}{P H_{2, \text { anode }}}\right)=\frac{\Delta G^{o}}{2 F}+\frac{R T}{2 F} \ln \left(\frac{P O_{2, \text { anode }}^{0.5} \cdot P H_{2, \text { cathode }}}{P H_{2} \mathrm{O}_{\text {anode }}}\right)
$$

The Type B half-cell based configuration's electrolysis current density reached $0.5 \mathrm{~A} \mathrm{~cm}^{-2}$ with an applied voltage of 1.56 at $600{ }^{\circ} \mathrm{C}$. In contrast, the Type $\mathrm{C}$ design attains $0.5 \mathrm{~A} \mathrm{~cm}^{-2}$ with applied voltages of $1.79,1.68,1.40 \mathrm{~V}$ at 500,550 , and $600{ }^{\circ} \mathrm{C}$, respectively. The overall cell overpotential decreased processively with an increase in temperature from 500 to $600{ }^{\circ} \mathrm{C}$, as shown in Figure 11a. A distinct non-linear $V-I$ slope behavior is exhibited at low current densities for all the cells up to about $100 \mathrm{~mA} / \mathrm{cm}^{2}$, with high activation overpotential. Hence, indicating a more sluggish electrode reaction with decreasing temperature. The thermal-neutral voltage for steam electrolysis, defined as the voltage at which the joule heating from the cell is equivalent to the endothermic heat demand, is $1.28 \mathrm{~V}$ at $600{ }^{\circ} \mathrm{C}$. Within this approximately applied voltage regime in Figure $11 \mathrm{a}$, the initial I-V curvature begins to shift to a constant slope. This slope change phenomenon could also be related to the cell's cooling via the endothermic energy demand [52,55]. It occurs $\sim 100 \mathrm{~mA} / \mathrm{cm}^{2}$ at $600{ }^{\circ} \mathrm{C}$ for Type $B$ and $C$ based cell configuration. An effective electrolyzer must convert a high fraction of the current into hydrogen; in other words, it should have high faradaic efficiency. The amount of hydrogen gas evolved at the cathode on passing a direct current through the cells was confirmed by gas chromatography. Figure $11 \mathrm{~b}$ presents the hydrogen evolution rate measured at 500,550 , and $600{ }^{\circ} \mathrm{C}$ versus current density.

The black dash line represents the theoretical evolution rate estimated from Faraday's law. The hydrogen evolution rate follows Faraday's law and is proportional to the current density even though deviations are noted at higher current densities. The faradaic efficiency was 84 and $82 \%$ at $500 \mathrm{~m} \mathrm{Acm}^{-2}$ for the Type B and C based cell configuration at $600{ }^{\circ} \mathrm{C}$, deviating from the faradaic efficiency. The deviation becomes more pronounced at 500 and $550{ }^{\circ} \mathrm{C}$. These substantial deviations are due to electronic current leakage through the BZCY $(54)_{8 / 9} 2$ electrolyte. It is well documented that the electronic transference number of ceramic proton conductors increases with increasing temperature and oxygen partial pressure $[16,56]$ and can, in principle, lower the current efficiency. Another plausible reason 
for the low current efficiency at $500{ }^{\circ} \mathrm{C}$ could be the anode material BLC's limited catalytic activity. The electrical energy efficiency of steam electrolysis, which is the amount of electrical energy input per unit of hydrogen produced, can be calculated using the following expression [3,57]:

$$
\begin{gathered}
\text { Electrical energy efficiency }\left(\eta_{E E}\right)=\frac{\text { Amount of } \mathrm{H}_{2} \text { production } \times \mathrm{LHVofH}_{2}}{\text { Electrical energy imput }} \times(F E) \times 100 \% \\
\eta_{E E}=\frac{\Delta H}{2 F V}=\frac{1.28 \text { volts }}{V} \times(F E) \times 100 \%
\end{gathered}
$$

where $E E$ is the energy efficiency, $F E$ is the faradaic efficiency, $\Delta H$ is the enthalpy change of hydrogen $\left(246.69 \mathrm{~kJ} / \mathrm{mol}\right.$ at $\left.600{ }^{\circ} \mathrm{C}\right)$, and $V$ is the applied voltage, $F$ is the Faraday constant. The electrical energy input per unit of hydrogen produced for the BZCY(54) $8 / 92$ cell at $500 \mathrm{~m} \mathrm{Acm}^{-2}$ with an applied voltage of $1.4 \mathrm{~V}$ is $\sim 77 \%$ (HHV standard). The amount of electricity required to produce $1 \mathrm{Nm}^{3}$ of hydrogen is $\left.\sim 3.9 \mathrm{kWh}\left(\left(1000 \mathrm{~L} \mathrm{Nm}^{-3}\right) /\left(22.4 \mathrm{~L} \mathrm{~mol}^{-1}\right) \times 2 F /\left(3600 \mathrm{~s} \mathrm{~h}^{-1}\right) \times(1.41 \mathrm{~V}) / 0.84\right)\right)(\mathrm{Wh})$. These results clearly demonstrated that sequential tape casting is a feasible approach for realizing the low-cost fabrication of high performing P-SOECs.

\section{Conclusions}

In summary, flat tri-layer $50 \times 50 \mathrm{~mm}^{2}$ planar barium cerium yttrium zirconate $\left(\mathrm{BZCY}(54)_{8 / 9} 2\right)$ half cells were processed via a cost-effective, scalable, sequential tape casting route. The shrinkage of the $\mathrm{NiO}-\mathrm{SZr}_{0.5} \mathrm{Ce}_{0.4} \mathrm{Y}_{0.1} \mathrm{O}_{2.95}$ support during co-sintering uniformly promotes the densification of the $\mathrm{BZCY}(54)_{8 / 9} 2$ electrolyte layer, thereby resulting in a remarkably reduced temperature of $1350{ }^{\circ} \mathrm{C}$. Furthermore, a typical BZCY $(54)_{8 / 9} 2$ based single cell at $600{ }^{\circ} \mathrm{C}$ reached reproducible terminal voltages of $1.4 \mathrm{~V} @ 500 \mathrm{~mA} \mathrm{~cm}^{-2}$, achieving $~ 84 \%$ faradaic efficiency regarding hydrogen production. Based on these results, the calculated amount of electricity to produce $1 \mathrm{Nm}^{3}$ of $\mathrm{H}_{2}$ is $\sim 3.9 \mathrm{kWh}$. Additional performance improvement is possible by further reducing the BZCY(54) $8 / 92$ electrolyte thickness, exploring more efficient electrode materials, and optimizing the cell microstructure. Future work will focus on the cells' characterization with an active area of $20 \mathrm{~cm}^{2}$ and strategies to mitigate electronic current leakages in protonic electrolysis cells.

Supplementary Materials: The following are available online at http://www.mdpi.com/2077-0375/10/11/339/s1, Figure S1: X-ray diffraction patterns of commercial SZCY541 and BZCY $(54)_{8 / 9} 2$ powders from KUSAKA RARE METAL PRODUCTS Co., LTD, Kanagawa, Japan. Figure S2: SEM morphology of BZCY(54) 8/9 $_{2}$ powders (a) Purchased powder from KUSAKA RARE METAL PRODUCTS Co., LTD, Kanagawa, Japan, as calcined at $1200{ }^{\circ} \mathrm{C}$ (b) In house synthesized after calcination at $1300{ }^{\circ} \mathrm{C}$ and milling, FS3: XRD patterns of green $\mathrm{NiO}-\mathrm{BZCY}(54)_{8 / 9} 2$ electrode substrate and after sintering at 1350 and $1450{ }^{\circ} \mathrm{C}$, Video S1: Shape evolution and bending behavior of the half-cell during sintering.

Author Contributions: Conceptualization, H.M., W.A.M., T.I., and K.L.; Methodology, K.L., W.A.M., and M.E.I.; Validation, K.L., W.D., and M.E.I.; Investigation, K.L.; Resources, H.M., W.A.M., and T.I.; Writing-Original Draft Preparation, K.L.; Funding Acquisition H.M., W.A.M., and T.I. All authors have read and agreed to the published version of the manuscript.

Funding: This research was funded by the International Institute for Carbon-Neutral Energy Research (I2CNER) sponsored by the World Premier International Research Center Initiative (WPI), MEXT Japan, the Ministry of Economy, Trade, and Industry (METI), Grants-in-Aid for Scientific Research <KAKENHI> grant number [19K05672] and JSPS Core-to-Core Program of Advanced Research Networks (Solid Oxide Interfaces for Faster Ion Transport).

Acknowledgments: The authors gratefully acknowledge D. Sebold, of IEK-1 Forschungszentrum Jülich and Matuda of Kyushu University, for SEM measurements. Norbert H. Menzler for useful discussions on SOEC processing, Volker Bader for specimen sintering, Mark Kappertz, and DI Marie-Theres Gerhards for experimental measurements and assistance. Financial support from the Cross-ministerial Strategic Innovation Promotion Program (SIP), "energy carrier"(Funding agency: JST) is gratefully acknowledged.

Conflicts of Interest: The authors declare no conflict of interest. The founding sponsors had no role in the design of the study, interpretation of data, writing of the manuscript, and publishing of the results. 


\section{References}

1. Iwahara, H.; Uchida, H.; Maeda, N. High temperature fuel and steam electrolysis cells using proton conductive solid electrolytes. J. Power Sources 1982, 7, 293-301. [CrossRef]

2. Duan, C.; Kee, R.; Zhu, H.; Sullivan, N.; Zhu, L.; Bian, L.; Jennings, D.; O’Hayre, R. Highly efficient reversible protonic ceramic electrochemical cells for power generation and fuel production. Nat. Energy 2019, 4, 230-240. [CrossRef]

3. Leonard, K.; Okuyama, Y.; Takamura, Y.; Lee, Y.-S.; Miyazaki, K.; Ivanova, M.E.; Meulenberg, W.A.; Matsumoto, $\mathrm{H}$. Efficient intermediate-temperature steam electrolysis with $\mathrm{Y}: \mathrm{SrZrO}_{3}-\mathrm{SrCeO}_{3}$ and Y: $\mathrm{BaZrO}_{3}-\mathrm{BaCeO}_{3}$ proton conducting perovskites. J. Mater. Chem. A 2018, 6, 19113-19124. [CrossRef]

4. Choi, S.; Davenport, T.C.; Haile, S.M. Protonic ceramic electrochemical cells for hydrogen production and electricity generation: Exceptional reversibility, stability, and demonstrated faradaic efficiency. Energy Environ. Sci. 2019, 12, 206-215. [CrossRef]

5. Vøllestad, E.; Strandbakke, R.; Tarach, M.; Catalán-Martínez, D.; Fontaine, M.-L.; Beeaff, D.; Clark, D.R.; Serra, J.M.; Norby, T. Mixed proton and electron conducting double perovskite anodes for stable and efficient tubular proton ceramic electrolysers. Nat. Mater. 2019, 18, 752-759. [CrossRef]

6. Kreuer, K.D. Proton-Conducting Oxides. Annu. Rev. Mater. Res. 2003, 33, 333-359. [CrossRef]

7. Leonard, K.; Lee, Y.-S.; Okuyama, Y.; Miyazaki, K.; Matsumoto, H. Influence of dopant levels on the hydration properties of SZCY and BZCY proton conducting ceramics for hydrogen production. Int. J. Hydrog. Energy 2017, 42, 3926-3937. [CrossRef]

8. Lei, L.; Zhang, J.; Yuan, Z.; Liu, J.; Ni, M.; Chen, F. Progress Report on Proton Conducting Solid Oxide Electrolysis Cells. Adv. Funct. Mater. 2019, 29, 1-17. [CrossRef]

9. Medvedev, D. Trends in research and development of protonic ceramic electrolysis cells. Int. J. Hydrog. Energy 2019, 44, 26711-26740. [CrossRef]

10. Grover, C.W. Co-Ionic Conduction in Protonic Ceramics of the Solid Solution, BaCe $(x) \mathrm{Zr}(y-x) Y(1-y) O 3-\delta$ Part I: Fabrication and Microstructure, Adances in Ceramic Synthesis and Characterisation, Processing and Specific Application; Costas Sikalidis, Ed.; In Tech: Rijeka, Croatia, 2018; pp. 479-499. ISBN 978-953-307-505-1.

11. Fujisaki, T.; Staykov, A.T.; Jing, Y.; Leonard, K.; Aluru, N.R.; Matsumoto, H. Understanding the effect of Ce and $\mathrm{Zr}$ on chemical expansion in yttrium doped strontium cerate and zirconate by high temperature $\mathrm{X}$-ray analysis and density functional theory. Solid State Ion. 2019, 333, 1-8. [CrossRef]

12. Strandbakke, R.; Cherepanov, V.A.; Zuev, A.Y.; Tsvetkov, D.S.; Argirusis, C.; Sourkouni, G.; Prünte, S.; Norby, T. Gd- and Pr-based double perovskite cobaltites as oxygen electrodes for proton ceramic fuel cells and electrolyser cells. Solid State Ion. 2015, 278, 120-132. [CrossRef]

13. Leonard, K.; Druce, J.; Thoréton, V.; Kilner, J.A.; Matsumoto, H. Exploring mixed proton/electron conducting air electrode materials in protonic electrolysis cell. Solid State Ion. 2018, 319, 218-222. [CrossRef]

14. Poetzsch, D.; Merkle, R.; Maier, J. Proton conductivity in mixed-conducting BSFZ perovskite from thermogravimetric relaxation. Phys. Chem. Chem. Phys. 2014, 16, 16446-16453. [CrossRef] [PubMed]

15. Tellez, H.; Druce, J.; Cooper, S.J.; Kilner, J. Double perovskite cathodes for proton-conducting ceramic fuel cells: Are they triple mixed ionic electronic conductors? Sci. Technol. Adv. Mater. 2017, 18, 977-986. [CrossRef] [PubMed]

16. Ambrosini, A.; Ricote, S.; Sullivan, N.P. Characterization of ionic transport through $\mathrm{BaCe}_{0.2} \mathrm{Zr}_{0.7} \mathrm{Y}_{0.1} \mathrm{O}_{3-\delta}$ membranes in galvanic and electrolytic operation. Int. J. Hydrog. Energy 2015, 40, 9278-9286. [CrossRef]

17. Matsumoto, H.; Sakai, T.; Okuyama, Y. Proton-conducting oxide and applications to hydrogen energy devices. Pure Appl. Chem. 2012, 85, 427-435. [CrossRef]

18. Gan, Y.; Zhang, J.; Li, Y.; Li, S.; Xie, K.; Irvine, J.T.S. Composite Oxygen Electrode Based on LSCM for Steam Electrolysis in a Proton Conducting Solid Oxide Electrolyzer. J. Electrochem. Soc. 2012, 159, F763-F767. [CrossRef]

19. Kim, J.; Jun, A.; Gwon, O.; Yoo, S.; Liu, M.; Shin, J.; Lim, T.-H.; Kim, G. Hybrid-solid oxide electrolysis cell: A new strategy for efficient hydrogen production. Nano Energy 2018, 44, 121-126. [CrossRef]

20. Wu, W.; Ding, H.; Zhang, Y.; Ding, Y.; Katiyar, P.; Majumdar, P.K.; He, T.; Ding, D. 3D Self-Architectured Steam Electrode Enabled Efficient and Durable Hydrogen Production in a Proton-Conducting Solid Oxide Electrolysis Cell at Temperatures Lower Than $600{ }^{\circ}$ C. Adv. Sci. 2018, 5, 1800360. [CrossRef] 
21. Schafbauer, W.; Schulze-Küppers, F.; Baumann, S.; Meulenberg, W.A.; Menzler, N.H.; Buchkremer, H.P.; Stöver, D. Tape Casting as a Multi Purpose Shaping Technology for Different Applications in Energy Issues. Mater. Sci. Forum 2012, 706, 1035-1040. [CrossRef]

22. Costa, R.; Hafsaoui, J.; De Oliveira, A.P.A.; Grosjean, A.; Caruel, M.; Chesnaud, A.; Thorel, A. Tape casting of proton conducting ceramic material. J. Appl. Electrochem. 2008, 39, 485-495. [CrossRef]

23. Menzler, N.H.; Malzbender, J.; Schoderböck, P.; Kauert, R.; Buchkremer, H.P. Sequential Tape Casting of Anode-Supported Solid Oxide Fuel Cells. Fuel Cells 2014, 14, 537. [CrossRef]

24. Fontaine, M.-L.; Larring, Y.; Smith, J.; Raeder, H.; Andersen, Ø.S.; Einarsrud, M.A.; Wiik, K.; Bredesen, R. Shaping of advanced asymmetric structures of proton conducting ceramic materials for SOFC and membrane-based process applications. J. Eur. Ceram. Soc. 2009, 29, 931-935. [CrossRef]

25. Zhao, C.; Liu, R.; Wang, S.; Wen, T. Fabrication of a large area cathode-supported thin electrolyte film for solid oxide fuel cells via tape casting and co-sintering techniques. Electrochem. Commun. 2009, 11, 842-845. [CrossRef]

26. Marrony, M.; Ancelin, M.; Lefèvre, G.; Dailly, J. Elaboration of intermediate size planar proton conducting solid oxide cell by wet chemical routes: A way to industrialization. Solid State Ion. 2015, 275, 97-100. [CrossRef]

27. Dailly, J.; Marrony, M. BCY-based proton conducting ceramic cell: $1000 \mathrm{~h}$ of long term testing in fuel cell application. J. Power Sources 2013, 240, 323-327. [CrossRef]

28. Marrony, M.; Dailly, J. Advanced Proton Conducting Ceramic Cell as Energy Storage Device. ECS Meet. Abstr. 2017, 164, 988. [CrossRef]

29. Bae, K.; Noh, H.-S.; Jang, D.Y.; Kim, M.; Kim, H.J.; Hong, J.; Lee, J.-H.; Kim, B.-K.; Son, J.-W.; Shim, J.H. Fabrication of NiO-Y:BaZrO 3 Composite Anode for Thin Film-Protonic Ceramic Fuel Cells using Tape-Casting. J. Korean Ceram. Soc. 2015, 52, 320-324. [CrossRef]

30. Orui, H.; Nozawa, K.; Chiba, R.; Komatsu, T.; Watanabe, K.; Sugita, S.; Arai, H.; Arakawa, M. Development of Anode Supported Solid Oxide Fuel Cells using LaNi(Fe)O 3 for Cathodes. ECS Trans. 2019, 7, $255-261$. [CrossRef]

31. Deibert, W.; Ivanova, M.E.; Meulenberg, W.A.; Vaßen, R.; Guillon, O. Preparation and sintering behaviour of $\mathrm{La}_{5.4} \mathrm{WO}_{12-\delta}$ asymmetric membranes with optimised microstructure for hydrogen separation. J. Memb. Sci. 2015, 492, 439-451. [CrossRef]

32. Ivanova, M.E.; Escolástico, S.; Balaguer, M.; Palisaitis, J.; Sohn, Y.J.; Meulenberg, W.A.; Guillon, O.; Mayer, J.; Serra, J.M. Hydrogen separation through tailored dual phase membranes with nominal composition $\mathrm{BaCe}_{0.8} \mathrm{Eu}_{0.2} \mathrm{O}_{3-\delta}: \mathrm{Ce}_{0.8} \mathrm{Y}_{0.2} \mathrm{O}_{2-\delta}$ at intermediate temperatures. Sci. Rep. 2016, 6, 34773. [CrossRef] [PubMed]

33. Fedeli, P.; Drago, F.; Schulze-Kuppers, F.; Baumann, S. Asymmetric LSCF Membranes Utilizing Commercial Powders. Materials. 2020, 13, 614. [CrossRef] [PubMed]

34. Schulze-Küppers, F.; Baumann, S.; Meulenberg, W.A.; Stöver, D.; Buchkremer, H.-P. Manufacturing and performance of advanced supported $\mathrm{Ba}_{0.5} \mathrm{Sr}_{0.5} \mathrm{Co}_{0.8} \mathrm{Fe}_{0.2} \mathrm{O}_{3-\delta}$ (BSCF) oxygen transport membranes. J. Membr. Sci. 2013, 433, 121-125. [CrossRef]

35. Meulenberg, W.A.; Schulze-Küppers, F.; Deibert, W.; Van Gestel, T.; Baumann, S. Ceramic Membranes: Materials-Components-Potential Applications. Chem. Biol. Eng. Rev. 2019, 6, 198-208. [CrossRef]

36. Takamura, Y.; Leonard, K.; Luo, A.; Martin, L.W.; Matsumoto, H. Platinum nanoparticle induced nanoionic effects on electrical conduction in strontium cerate and zirconate. J. Solid State Electrochem. 2019, 23, 953-963. [CrossRef]

37. Gaudon, M.; Menzler, N.H.; Djurado, E.; Buchkremer, H.P. YSZ electrolyte of anode-supported SOFCs prepared from sub micron YSZ powders. J. Mater. Sci. 2005, 40, 3735-3743. [CrossRef]

38. Ivanova, M.E.; Deibert, W.; Marcano, D.; Escolástico, S.; Mauer, G.; Meulenberg, W.; Bram, M.; Serra, J.; Vaßen, R.; Guillon, O. Lanthanum tungstate membranes for $\mathrm{H} 2$ extraction and $\mathrm{CO}_{2}$ utilization: Fabrication strategies based on sequential tape casting and plasma-spray physical vapor deposition. Sep. Purif. Technol. 2019, 219, 100-112. [CrossRef]

39. Natividad, S.L.; Marotto, V.R.; Walker, L.S.; Pham, D.; Pinc, W.; Corral, E.L. Tape Casting Thin, Continuous, Homogenous, and Flexible Tapes of ZrB2. J. Am. Ceram. Soc. 2011, 94, 2749-2753. [CrossRef]

40. Lim, K.Y.; Kim, D.H.; Paik, U.; Kim, S.H. Effect of the molecular weight of poly(ethylene glycol) on the plasticization of green sheets composed of ultrafine $\mathrm{BaTiO}_{3}$ particles and poly(vinyl butyral). Mater. Res. Bull. 2003, 38, 1021-1032. [CrossRef] 
41. Shende, R.V.; Lombardo, S.J. Determination of Binder Decomposition Kinetics for Specifying Heating Parameters in Binder Burnout Cycles. J. Am. Ceram. Soc. 2004, 85, 780-786. [CrossRef]

42. Ren, L.; Luo, X.; Zhou, H. The tape casting process for manufacturing low-temperature co-fired ceramic green sheets: A review. J. Am. Ceram. Soc. 2018, 101, 3874-3889. [CrossRef]

43. Babilo, P.; Uda, T.; Haile, S.M. Processing of yttrium-doped barium zirconate for high proton conductivity. J. Mater. Res. 2007, 22, 1322-1330. [CrossRef]

44. Kaiser, A.; Prasad, A.; Foghmoes, S.P.V.; Ramousse, S.; Bonanos, N.; Esposito, V. Sintering process optimization for multi-layer CGO membranes by in situ techniques. J. Eur. Ceram. Soc. 2013, 33, 549-556. [CrossRef]

45. Green, D.J.; Guillon, O.; Rödel, J. Constrained sintering: A delicate balance of scales. J. Eur. Ceram. Soc. 2008, 28, 1451-1466. [CrossRef]

46. Cai, P.Z.; Green, D.J.; Messing, G.L. Constrained Densification of Alumina/Zirconia Hybrid Laminates, II: Viscoelastic Stress Computation. J. Am. Ceram. Soc. 2005, 80, 1940-1948. [CrossRef]

47. Cai, P.Z.; Green, D.J.; Messing, G.L. Constrained Densification of Alumina/Zirconia Hybrid Laminates, I: Experimental Observations of Processing Defects. J. Am. Ceram. Soc. 2005, 80, 1929-1939. [CrossRef]

48. Ravi, D.; Green, D.J. Sintering stresses and distortion produced by density differences in bi-layer structures. J. Eur. Ceram. Soc. 2006, 26, 17-25. [CrossRef]

49. Yoo, Y.; Lim, N. Performance and stability of proton conducting solid oxide fuel cells based on yttrium-doped barium cerate-zirconate thin-film electrolyte. J. Power Sources 2013, 229, 48-57. [CrossRef]

50. Tong, J.; Clark, D.; Bernau, L.; Subramaniyan, A.; O'Hayre, R. Proton-conducting yttrium-doped barium cerate ceramics synthesized by a cost-effective solid-state reactive sintering method. Solid State Ion. 2010, 181, 1486-1498. [CrossRef]

51. An, H.; Lee, H.W.; Kim, B.K.; Son, J.W.; Yoon, K.J.; Kim, H.; Shin, D.; Ji, H.I.; Lee, J.H. A $5 \times 5 \mathrm{~cm}^{2}$ protonic ceramic fuel cell with a power density of $1.3 \mathrm{~W} \mathrm{~cm}^{-2}$ at $600{ }^{\circ} \mathrm{C}$. Nat. Energy 2018, 3, 870-875. [CrossRef]

52. Azimova, M.A.; McIntosh, S. On the reversibility of anode supported proton conducting solid oxide cells. Solid State Ion. 2011, 203, 57-61. [CrossRef]

53. Taniguchi, N.; Hatoh, K.; Niikura, J.; Gamo, T.; Iwahara, H. Proton conductive properties of gadolinium-doped barium cerates at high temperatures. Solid State Ion. 1992, 998-1003. [CrossRef]

54. Maeda, S.; Shiratori, Y.; Kurashina, D.; Fujisaki, T.; Leonard, K.; Matsumoto, H. Electrochemical reforming of methane using $\mathrm{SrZr} 0.5 \mathrm{Ce} 0.4 \mathrm{Y} 0.1 \mathrm{O} 3-\delta$ proton-conductor cell combined with paper-structured catalyst. Int. J. Hydrog. Energy 2020, 45, 4026-4034. [CrossRef]

55. Wang, Z.; Mori, M.; Araki, T. Steam electrolysis performance of intermediate-temperature solid oxide electrolysis cell and efficiency of hydrogen production system at $300 \mathrm{Nm} 3 \mathrm{~h}-1$. Int. J. Hydrog. Energy 2010, 35, 4451-4458. [CrossRef]

56. Han, D.; Noda, Y.; Onishi, T.; Hatada, N.; Majima, M.; Uda, T. Transport properties of acceptor-doped barium zirconate by electromotive force measurements. Int. J. Hydrog. Energy 2016, 41, 14897-14908. [CrossRef]

57. Ishihara, T.; Kannou, T. Intermediate temperature steam electrolysis using $\mathrm{LaGaO}_{3}$-based electrolyte. Solid State Ion. 2011, 192, 642-644. [CrossRef]

Publisher's Note: MDPI stays neutral with regard to jurisdictional claims in published maps and institutional affiliations.

(C) 2020 by the authors. Licensee MDPI, Basel, Switzerland. This article is an open access article distributed under the terms and conditions of the Creative Commons Attribution (CC BY) license (http://creativecommons.org/licenses/by/4.0/). 